\title{
Coexistence of Microaerophilic, Nitrate-Reducing, and Phototrophic Fe(II) Oxidizers and Fe(III) Reducers in Coastal Marine Sediment
}

\author{
Katja Laufer, ${ }^{\text {a }}$ Mark Nordhoff, ${ }^{\text {a Hans Røy, }}{ }^{\text {c }}$ Caroline Schmidt, ${ }^{\text {a }}$ Sebastian Behrens, ${ }^{\text {a,b }}$ Bo Barker Jørgensen, ${ }^{\text {c }}$ Andreas Kappler ${ }^{\text {a,c }}$ \\ Geomicrobiology, Center for Applied Geosciences, University of Tübingen, Tübingen, Germany ${ }^{\text {; }}$ Department of Civil, Environmental, and Geo-Engineering, University of \\ Minnesota, Minneapolis, Minnesota, USA ${ }^{\mathrm{b}}$; Center for Geomicrobiology, Department of Bioscience, Aarhus University, Aarhus, Denmark
}

Iron is abundant in sediments, where it can be biogeochemically cycled between its divalent and trivalent redox states. The neutrophilic microbiological $\mathrm{Fe}$ cycle involves $\mathrm{Fe}$ (III)-reducing and three different physiological groups of $\mathrm{Fe}$ (II)-oxidizing microorganisms, i.e., microaerophilic, anoxygenic phototrophic, and nitrate-reducing $\mathrm{Fe}$ (II) oxidizers. However, it is unknown whether all three groups coexist in one habitat and how they are spatially distributed in relation to gradients of $\mathrm{O}_{2}$, light, nitrate, and $\mathrm{Fe}(\mathrm{II})$. We examined two coastal marine sediments in Aarhus Bay, Denmark, by cultivation and most probable number (MPN) studies for $\mathrm{Fe}(\mathrm{II})$ oxidizers and $\mathrm{Fe}(\mathrm{III})$ reducers and by quantitative-PCR (qPCR) assays for microaerophilic $\mathrm{Fe}(\mathrm{II})$ oxidizers. Our results demonstrate the coexistence of all three metabolic types of $\mathrm{Fe}(\mathrm{II})$ oxidizers and $\mathrm{Fe}(\mathrm{III})$ reducers. In qPCR, microaerophilic $\mathrm{Fe}$ (II) oxidizers (Zetaproteobacteria) were present with up to $3.2 \times 10^{6}$ cells g dry sediment $^{-1}$. In MPNs, nitrate-reducing $\mathrm{Fe}(\mathrm{II})$ oxidizers, anoxygenic phototrophic $\mathrm{Fe}(\mathrm{II})$ oxidizers, and $\mathrm{Fe}(\mathrm{III})$ reducers reached cell numbers of up to $3.5 \times 10^{4}, 3.1 \times$ $10^{2}$, and $4.4 \times 10^{4} \mathrm{~g}$ dry sediment ${ }^{-1}$, respectively. $\mathrm{O}_{2}$ and light penetrated only a few millimeters, but the depth distribution of the different iron metabolizers did not correlate with the profile of $\mathrm{O}_{2}, \mathrm{Fe}(\mathrm{II})$, or light. Instead, abundances were homogeneous within the upper $3 \mathrm{~cm}$ of the sediment, probably due to wave-induced sediment reworking and bioturbation. In microaerophilic $\mathrm{Fe}$ (II)-oxidizing enrichment cultures, strains belonging to the Zetaproteobacteria were identified. Photoferrotrophic enrichments contained strains related to Chlorobium and Rhodobacter; the nitrate-reducing $\mathrm{Fe}(\mathrm{II})$ enrichments contained strains related to Hoeflea and Denitromonas. This study shows the coexistence of all three types of $\mathrm{Fe}(\mathrm{II})$ oxidizers in two near-shore marine environments and the potential for competition and interrelationships between them.

ron occurs in natural environments with the oxidation state of $\mathrm{Fe}(\mathrm{II})$ or $\mathrm{Fe}(\mathrm{III})$. In the biogeochemical Fe cycle at neutral $\mathrm{pH}$, redox transformations of Fe are mediated by a variety of biotic and abiotic processes (1). In the biotic part of this cycle, different metabolic types of microorganisms are involved. Some microorganisms use $\mathrm{Fe}(\mathrm{III})$ as an electron acceptor for oxidation of organic carbon or hydrogen [Fe(III)-reducing bacteria] (2). Others use $\mathrm{Fe}(\mathrm{II})$ as an electron donor coupled with the reduction of $\mathrm{O}_{2}[\mathrm{mi}-$ croaerophilic $\mathrm{Fe}(\mathrm{II})$ oxidizers] (3) or nitrate [nitrate-reducing Fe(II) oxidizers] (4). Still others use Fe(II) as an electron donor for photosynthesis and couple $\mathrm{Fe}$ (II) oxidation with reduction (fixation) of $\mathrm{CO}_{2}$, with light as the energy source [anoxygenic phototrophic $\mathrm{Fe}$ (II) oxidizers; so-called photoferrotrophs] (5).

$\mathrm{Fe}(\mathrm{III})$-reducing microorganisms were discovered in the late 1980s (6). Many of the better-known Fe(III)-reducing bacteria of the genera Shewanella, Geobacter, and Geothrix are found mainly in freshwater and more rarely in marine sediments $(7,8)$. Still, $\mathrm{Fe}$ (III) reduction can account for a large fraction of organic-matter mineralization in coastal marine sediments (up to 50\%) (9).

$\mathrm{Fe}(\mathrm{II})$-oxidizing bacteria were first described in 1836 by Ehrenberg (10) as so-called "iron bacteria." It took more than a century before the first microbes belonging to this group could be grown in the laboratory (11) and even longer until it was demonstrated that they grow autotrophically by oxidizing $\mathrm{Fe}(\mathrm{II})$ with $\mathrm{O}_{2}(12)$. These bacteria face the problem that, at neutral $\mathrm{pH}$, the abiotic reaction of oxygen and $\mathrm{Fe}$ (II) is fast. Therefore, bacterial $\mathrm{Fe}(\mathrm{II})$ oxidation with $\mathrm{O}_{2}$ at neutral $\mathrm{pH}$ is limited to micro-oxic $\left(\left[\mathrm{O}_{2}\right]<\right.$ $50 \mu \mathrm{M})$ conditions, where microbial iron oxidation can compete favorably with the $\left[\mathrm{O}_{2}\right]$-limited abiotic reaction $(13,14)$. Favorable conditions for the growth of microaerophilic Fe(II) oxidizers are found in opposing gradients of $\mathrm{Fe}(\mathrm{II})$ and $\mathrm{O}_{2}$, e.g., in the oxic- anoxic transition zone in sediments or groundwater seeps (15). Today, there are at least four known groups of exclusively microaerophilic Fe(II) oxidizers, i.e., Gallionella (11, 12), Sideroxydans (3), Leptothrix $(16,17)$, and Mariprofundus (18). Furthermore, certain bacteria belonging to the genera Marinobacter and Hyphomonas are also described as growing under micro-oxic conditions by $\mathrm{Fe}$ (II) oxidation $(19,20)$.

The photoferrotrophs (5) are not only of interest for modern habitats, but may also be responsible for the formation of banded iron formations (BIFs) in the Precambrian $(21,22)$. Until now, only a few pure cultures have been known, and there is no known monophylogenetic group that specializes solely in anoxygenic phototrophic $\mathrm{Fe}$ (II) oxidation. Known strains are metabolically flexible and belong to various physiological groups of anoxygenic phototrophs, i.e., the purple sulfur, purple nonsulfur, and green anoxygenic phototrophic bacteria $(5,23-25)$.

For the nitrate-reducing $\mathrm{Fe}(\mathrm{II})$ oxidizers, most known strains cannot be maintained in culture over several transfers with nitrate

Received 29 October 2015 Accepted 14 December 2015 Accepted manuscript posted online 18 December 2015 Citation Laufer K, Nordhoff M, Røy H, Schmidt C, Behrens S, Jørgensen BB, Kapple A. 2016. Coexistence of microaerophilic, nitrate-reducing, and phototrophic Fe(II) oxidizers and Fe(III) reducers in coastal marine sediment. Appl Environ Microbiol 82:1433-1447. doi:10.1128/AEM.03527-15.

Editor: J. E. Kostka, Georgia Institute of Technology

Address correspondence to Andreas Kappler, andreas.kappler@uni-tuebingen.de. Supplemental material for this article may be found at http://dx.doi.org/10.1128 /AEM.03527-15.

Copyright $\odot$ 2016, American Society for Microbiology. All Rights Reserved. 
and $\mathrm{Fe}(\mathrm{II})$ alone but need an organic cosubstrate. For these mixotrophic strains, it is not yet known whether Fe(II) oxidation is just a chemical side reaction with nitrite, which is produced during heterotrophic denitrification $(26,27)$, or if it is an enzymatic reaction from which the bacteria can gain energy. Interestingly, $\mathrm{Fe}$ (II) oxidation seems to be a universal ability of all $\mathrm{NO}_{3}{ }^{-}$-reducing bacteria when an organic substrate is provided (28). A unique feature of this group of $\mathrm{Fe}(\mathrm{II})$ oxidizers is that the cells become encrusted with $\mathrm{Fe}$ (III) minerals during $\mathrm{Fe}(\mathrm{II})$ oxidation (27), a process that is potentially harmful to the cells (29). A few strains have been proposed to be able to live autotrophically with only $\mathrm{NO}_{3}{ }^{-}$and $\mathrm{Fe}(\mathrm{II})(4,30-35)$, although unambiguous evidence for this is missing. One enrichment culture, KS (4), can grow autotrophically and can be transferred and cultivated continuously with only $\mathrm{Fe}$ (II) and $\mathrm{NO}_{3}{ }^{-}$, but the mechanism of $\mathrm{Fe}(\mathrm{II})$ oxidation and the responsible strain in the coculture are still unknown.

For the three physiological types of Fe(II)-oxidizing bacteria, not much is known about their abundance and spatial distribution in marine sediments. It is known that microaerophilic Fe(II) oxidizers can reach numbers of up to $10^{7}$ cells $/ \mathrm{ml}$ in iron-rich marine environments, such as Fe(II)-containing hydrothermal vents $(36,37)$. While Gallionella, Sideroxydans, and Leptothrix seem to be restricted to limnic and terrestrial habitats, the genus Mariprofundus may be restricted to marine habitats (38-42). Information about the presence of photoferrotrophs in marine sediments is scarce, and there are only two isolates, Rhodovulum iodosum and Rhodovulum robiginosum, which were both isolated from a tidal mud flat in the German Wadden Sea $(43,44)$. Almost nothing is known about the abundance and activity of nitratereducing $\mathrm{Fe}$ (II) oxidizers in marine habitats. It was shown by Emmerich et al. (45) that nitrate-reducing Fe(II) oxidizers can be found in hypersaline lake sediments, and Rowe et al. (46) showed that microorganisms present in marine sediment have the capability to oxidize solid-phase $\mathrm{Fe}(\mathrm{II})$ with nitrate.

Until now, it has been unclear whether the three different metabolic types of $\mathrm{Fe}$ (II)-oxidizing bacteria coexist in one habitat and potentially compete or interact with each other. One of the reasons for this lack of knowledge is that there are no functional genes that are uniquely linked to $\mathrm{Fe}$ (II) oxidation. Thus, there are no general molecular markers available for Fe(II) oxidizers, and consequently, studies of the abundance and activity of Fe(II) oxidizers rely mostly on cultivation-dependent methods. Two exceptions are the marine group of microaerophilic Fe(II) oxidizers, the Zetaproteobacteria, and the freshwater Gallionella spp., since for these groups, specific $16 \mathrm{~S}$ rRNA primers are available for quantification. These two groups of microaerophilic $\mathrm{Fe}(\mathrm{II})$ oxidizers are monophyletic, and all known members are microaerophilic Fe(II) oxidizers.

A typical coastal marine sediment has pore water concentrations of $\mathrm{Fe}(\mathrm{II})$ of up to $150 \mu \mathrm{M}$, nitrate concentrations of around $10 \mu \mathrm{M}$, and $\mathrm{O}_{2}$ and light penetration depths of only a few millimeters (47-51). Therefore, there is potential for all three metabolic types of $\mathrm{Fe}$ (II) oxidizers to be present and active within the same sediment, and it can be expected that they show the highest abundances and activities in certain zones where the conditions are favorable. These Fe(II) oxidizers may live in association with $\mathrm{Fe}$ (III) reducers that provide the $\mathrm{Fe}$ (II) (52). It has been suggested that each ion of Fe is cycled on average 100 to 300 times before it is finally buried in the sediment (53). Based on the knowledge gaps described above, the goals of the present study were (i) to deter- mine the abundance and spatial distribution of the three metabolic types of $\mathrm{Fe}$ (II) oxidizers and the $\mathrm{Fe}$ (III) reducers in two typical but geochemically distinct marine coastal sediments; (ii) to determine how their spatial distribution relates to $\mathrm{O}_{2}$, nitrate, and light; and (iii) to enrich and isolate representative cultures of each group of $\mathrm{Fe}(\mathrm{II})$ oxidizers and $\mathrm{Fe}(\mathrm{III})$ reducers.

\section{MATERIALS AND METHODS}

Field sites and sampling of sediment. Sediment was sampled at two field sites in the Aarhus Bay area on the east coast of the peninsula of Jutland (Denmark). The field site called Norsminde Fjord is located in a shallow, brackish estuary with a narrow entrance from the Baltic Sea. Samples were taken near the entrance in the southeastern part of the fjord $\left(56^{\circ} 1.171^{\prime} \mathrm{N}\right.$, $10^{\circ} 15.390^{\prime} \mathrm{E}$ ). The water depth at the sampling site was about $0.5 \mathrm{~m}$, with no significant tidal variation, while the salinity varied from 14 to 23 depending on local wind and precipitation. The sediment was organic-rich black mud. The field site Kalø Vig is not influenced by local freshwater sources, and the salinity varies from 20 to 23 . Samples were taken directly along the sandy beach $\left(56^{\circ} 16.811^{\prime} \mathrm{N}, 10^{\circ} 28.056^{\prime} \mathrm{E}\right)$ at water depths ranging from 0.5 to $1 \mathrm{~m}$. The sediment was fine sand and silt with low organic matter content.

Samples were taken in different seasons from May 2013 until February 2015. For most geochemical and MPN data presented, sediment sampled in summer 2014 was used. Exceptions are the MPNs in deeper sediment layers (down to $18 \mathrm{~cm}$ ), which were sampled in February 2015. Sediments for enrichment cultures of $\mathrm{Fe}$ (II) oxidizers and $\mathrm{Fe}$ (III) reducers were sampled at different times, as indicated below, where the methods used for the enrichment cultures are described. Sediment cores 15 to $20 \mathrm{~cm}$ long and with $2.5-\mathrm{cm}$ inner diameters were taken with core liners made of $50-\mathrm{ml}$ syringes with the front ends cut off. These core liners fit into a self-made slicing device, which enables sediment cores to be sliced with a depth resolution of $1 \mathrm{~mm}$ (54). Water samples for analysis of the overlying water were taken in 50-ml Falcon tubes. Processing of sediment samples for all measurements and analyses were performed as fast as possible after sampling of the sediment (a maximum of 2 days after sampling), and sediment was stored at $4^{\circ} \mathrm{C}$ until it was processed. Microsensor measurements were done directly after sampling.

Measurements in the field. The temperature, $\mathrm{pH}$, salinity, and oxygen saturation of the water were measured directly in the field with a field multimeter (WTW; Multi 3430) equipped with a pH electrode with a temperature sensor (WTW; SenTrix), a conductivity electrode (WTW; TetraCon92), and an oxygen sensor (WTW; FDO925).

Microsensor measurements. Microsensor measurements were performed at in situ temperatures directly at the field site immediately after sampling. High-resolution profiles of dissolved $\mathrm{O}_{2}, \mathrm{pH}$, gaseous $\mathrm{H}_{2} \mathrm{~S}$, and redox potential were measured with commercially available glass microelectrodes with a $100-\mu \mathrm{m}$ tip diameter (Unisense, Denmark). Vertical profiles of oxygen were measured with a depth resolution of $200 \mu \mathrm{m}$ and the remaining parameters with a resolution of $500 \mu \mathrm{m}$, using a manual micromanipulator. Data were recorded with the software Sensor Trace Pro (Unisense, Denmark). Before and during measurements, the overlying water in the sediment cores was aerated to prevent gradients in the overlying liquid phase. For each parameter, triplicate profiles were measured in each sediment core at different positions in the core. Concentrations of total sulfide $\left(\mathrm{H}_{2} \mathrm{~S}, \mathrm{HS}^{-}\right.$, and $\left.\mathrm{S}^{2-}\right)$ were calculated with the respective $\mathrm{pH}$ values at the same sediment depth by calculation of the $\mathrm{pK}_{\mathrm{a}}$.

Light profiles of scalar irradiance in the sediment cores were measured with self-made light sensors (55) connected to a spectrometer (USB4000; Ocean Optics, Germany). Profiles were measured with a resolution of 200 $\mu \mathrm{m}$. For the measurements, sediment cores were illuminated with a halogen cold-light source (Euromex EK-1; Holland) from two sides. This sensor measured the scalar irradiance with wavelengths from 200 to 1,000 $\mathrm{nm}$. Data were recorded with the software Spectra View (Ocean Optics, Germany). The scalar irradiance within the sediment was normalized to the irradiance in the supernatant of the core. 
Pore water content and pore water geochemistry. The pore water content of the sediment was determined by weighing sediment slices (0.5-cm intervals from 0 - to 3-cm depth) before and after drying the sediment for 3 days at $80^{\circ} \mathrm{C}$. The dissolved organic carbon content (DOC) was measured in the water column and the sediment pore water. For pore water analysis of the DOC, nitrate, and nitrite, sediment from the upper 0 to $3 \mathrm{~cm}$ of a sediment core was centrifuged ( $15 \mathrm{~min} ; 7,000 \times \mathrm{g}$; Eppendorf 5430R). For DOC measurements after centrifugation, the supernatant was filtered through a $0.45-\mu \mathrm{m}$ filter. The overlying water was also filtered through a $0.45-\mu \mathrm{m}$ filter, and the DOC concentration was measured with a carbon analyzer (highTOC; Elementar, Germany). Nitrate and nitrite were quantified with a flow injection analyzer (FIA) equipped with a dialysis membrane that removed the iron to prevent side reactions during the measurement (Seal Analytical, Germany).

Fe content and Fe speciation in pore water and sediment. To determine the $\mathrm{Fe}$ concentration and speciation in pore water, sediment cores were sliced in an anoxic glove box $\left(100 \% \mathrm{~N}_{2}\right.$ atmosphere $)$ in 0.5 -cm steps. Pore water was obtained by centrifugation of small amounts of sediment for $5 \mathrm{~min}$ at 12,000 $\times g$ (Eppendorf MiniSpin) in spin filters (Costar Spin-X Centrifuge tube filter; $0.22-\mu \mathrm{m}$ nylon). To maintain Fe redox speciation, the pore water was mixed in a 1:1 ( $\mathrm{vol} / \mathrm{vol})$ ratio with anoxic 1 $\mathrm{M} \mathrm{HCl}$. For determination of the Fe content and speciation in the sediment, a sequential Fe extraction was performed. Fe was extracted from $0.25 \mathrm{~g}$ sediment, first for $1 \mathrm{~h}$ with $0.5 \mathrm{M} \mathrm{HCl}$ (bioavailable fraction) and then for $24 \mathrm{~h}$ at $70^{\circ} \mathrm{C}$ in $6 \mathrm{M} \mathrm{HCl}$ (crystalline fraction). All extraction steps were performed under anoxic conditions $\left(100 \% \mathrm{~N}_{2}\right.$ atmosphere) to avoid changes in Fe redox speciation during extraction due to $\mathrm{O}_{2}$ (56). After both extraction steps, the samples were centrifuged for $15 \mathrm{~min}$ at 5,000 $\times$ $g$ (Hermle 7300). Then, $200 \mu \mathrm{l}$ of the supernatant was stabilized in $800 \mu \mathrm{l}$ of $1 \mathrm{M}$ anoxic $\mathrm{HCl}$. $\mathrm{Fe}$ (II) and total Fe concentrations were determined by the spectrophotometric Ferrozine assay in triplicate (57) with a spectrophotometric plate reader (FlashScan 550; Analytic, Jena, Germany). For calculation of $\mathrm{Fe}$ (III) concentrations, the concentration of $\mathrm{Fe}(\mathrm{II})$ was subtracted from the total Fe concentration.

Enrichment and enumeration of Fe-metabolizing bacteria. For enrichment and enumeration of the different types of bacteria, anoxic artificial seawater (ASW) medium with a salinity of 23 was used. Per liter, it contained the following salts: $17.3 \mathrm{~g} \mathrm{NaCl}, 8.6 \mathrm{~g} \mathrm{MgCl}_{2} \cdot 6 \mathrm{H}_{2} \mathrm{O}, 0.025 \mathrm{~g}$ $\mathrm{MgSO}_{4} \cdot 7 \mathrm{H}_{2} \mathrm{O}, 0.99 \mathrm{~g} \mathrm{CaCl}_{2} \cdot 2 \mathrm{H}_{2} \mathrm{O}, 0.39 \mathrm{~g} \mathrm{KCl}, 0.059 \mathrm{~g} \mathrm{KBr}, 0.25 \mathrm{~g} \mathrm{NH}_{4} \mathrm{Cl}$, and $0.05 \mathrm{~g} \mathrm{KH}_{2} \mathrm{PO}_{4}$. The medium was prepared anoxically with a headspace of $\mathrm{N}_{2}-\mathrm{CO}_{2}$ (90:10) in a Widdel flask and buffered with $22 \mathrm{mM}$ bicarbonate buffer. Additionally, per liter, $1 \mathrm{ml}$ of a vitamin solution (58), $1 \mathrm{ml}$ of a trace element solution (59), and $1 \mathrm{ml}$ of a selenite-tungstate solution (60) were added. The $\mathrm{pH}$ of the medium was adjusted to 7.1 with either anoxic $1 \mathrm{M} \mathrm{HCl}$ or anoxic $0.5 \mathrm{M} \mathrm{Na}_{2} \mathrm{CO}_{3}$. For enrichment and enumeration of microaerophilic $\mathrm{Fe}(\mathrm{II})$ oxidizers, the ASW medium was slightly altered. Instead of $0.05 \mathrm{~g} \mathrm{KH}_{2} \mathrm{PO}_{4}, 0.05 \mathrm{~g} \mathrm{~K}_{2} \mathrm{HPO}_{4}$ was used, and the concentration of the bicarbonate buffer was lowered to $10 \mathrm{mM}$.

Enrichment of Fe-metabolizing bacteria. Enrichment of microaerophilic $\mathrm{Fe}(\mathrm{II})$ oxidizers was done in petri dishes (55-mm diameter) with zero-valent iron (ZVI) powder (200 mesh; metal basis; Alfa Aesar, Ward Hill, MA). This method is similar to that described by McBeth et al. (38) and is referred to here as ZVI plates. All work with microaerophilic Fe(II) oxidizers was done under oxic and sterile conditions. For the initial inoculation, ca. $0.1 \mathrm{~g}$ homogenized sediment from the uppermost $3 \mathrm{~cm}$ of a sediment core was added to a petri dish containing ca. $60 \mathrm{mg}$ ZVI and $8 \mathrm{ml}$ anoxic ASW and mixed gently. The sediment for the enrichments presented in this paper was sampled in October 2013. By adding $100 \mu$ lof this first dilution to another petri dish containing ca. $60 \mathrm{mg} \mathrm{ZVI}$ and $8 \mathrm{ml}$ ASW, the sample was further diluted. This dilution step was repeated 5 times. After preparation, the petri dishes were incubated in an acrylic anaerobic jar (Merck, Germany), together with a gas pack that produced a micro-oxic atmosphere with a 6 to $10 \%$ atmospheric $\mathrm{O}_{2}$ concentration (BD GasPack EZ Campy; Becton, Dickinson and Co., NJ). After 2 to 3 days, the growth of microaerophilic Fe(II) oxidizers was checked by fluo- rescence microscopy, for which cells were stained by LIVE/DEAD staining (BacLight; Invitrogen, Carlsbad, CA). The highest positive dilution at which growth of microaerophilic Fe(II) oxidizers was observed, i.e., where formation of characteristic twisted stalks was observed, was used for preparation of a new dilution series. The enrichments were subjected to several such dilution-to-extinction series. To test for aerobic heterotrophic bacteria in the enrichments, streakouts on oxic R2A-ASW plates were done.

For enrichments of anaerobic $\mathrm{Fe}(\mathrm{II})$ oxidizers and $\mathrm{Fe}(\mathrm{III})$ reducers in the first two dilution series, $2 \mathrm{mM} \mathrm{Na}_{2} \mathrm{MoO}_{4}$ was added to the medium in order to inhibit $\mathrm{SO}_{4}{ }^{2-}$ reduction and production of $\mathrm{H}_{2} \mathrm{~S}(61,62)$. All work with the anaerobic $\mathrm{Fe}(\mathrm{II})$ oxidizers and $\mathrm{Fe}(\mathrm{III})$ reducers was done under sterile and anoxic conditions. All enrichment cultures were grown in 15-ml Hungate tubes containing $9 \mathrm{ml}$ ASW medium with different amendments. The headspace was $\mathrm{N}_{2}: \mathrm{CO}_{2}(90: 10)$. Dilution series were prepared by adding $1 \mathrm{~g}$ of homogenized sediment from the uppermost 3 $\mathrm{cm}$ of a sediment core to a Hungate tube with $9 \mathrm{ml}$ of medium. A 10-fold dilution series was then prepared up to a dilution of $10^{-6}$ in ASW medium. After 4 to 5 weeks of incubation, a new dilution series was set up with two dilution steps higher than the highest positive dilution of the previous dilution series. If $\mathrm{Fe}$ (II) oxidation activity was found up to a dilution of $10^{-6}$, the new dilution series was prepared with dilutions up to $10^{-8}$ with the goal of reaching dilution to extinction so that in the highest dilutions no growth was observed. The growth and homogeneity of the enrichment cultures were checked before each transfer by fluorescence microscopy and LIVE/DEAD staining. Anoxic enrichments of photoferrotrophs were made in ASW medium amended with $10 \mathrm{mM} \mathrm{FeCl}_{2}$. The tubes were then incubated in the light (15-W fluorescent tube; 5,500 K) at $20^{\circ} \mathrm{C}$. The enrichments presented in this article were inoculated with sediment that was sampled in May 2013 (Norsminde Fjord) and August 2013 (Kalø Vig). Anoxic enrichments of autotrophic and mixotrophic nitratereducing $\mathrm{Fe}$ (II) oxidizers were set up in ASW medium amended with 10 $\mathrm{mM} \mathrm{FeCl}_{2}$ and $4 \mathrm{mM} \mathrm{NO}_{3}{ }^{-}$and with or without addition of $5 \mathrm{mM}$ acetate. The headspace was $\mathrm{N}_{2}-\mathrm{CO}_{2}(90: 10)$. The sediment for setting up the enrichments of nitrate-reducing $\mathrm{Fe}(\mathrm{II})$ oxidizers that are presented here was sampled in January 2014. Transfers of the highest positive dilution of anaerobic $\mathrm{Fe}$ (II) oxidizers were done after the development of an orangebrown rusty color, indicating the activity of $\mathrm{Fe}(\mathrm{II})$ oxidizers.

Enrichments for $\mathrm{Fe}(\mathrm{III})$ reducers were set up in ASW medium amended with $5 \mathrm{mM}$ ferrihydrite, prepared according to the method of Straub et al. (63), plus $5 \mathrm{mM}$ acetate, $5 \mathrm{mM}$ lactate, and $2 \mathrm{mM} \mathrm{Na}_{2} \mathrm{MoO}_{4}$. The sediment for the enrichments that are presented here was sampled in October 2013. Activity of Fe(III) reducers in these enrichments was obvious when the red color of the ferrihydrite changed to black.

SEM. Scanning electron microscopy (SEM) was used to characterize the structure of the stalks formed in microaerophilic enrichment cultures at high resolution. Culture samples from ZVI plates were washed in sterile anoxic distilled water and filtered onto $0.2-\mathrm{mm}$-pore-size polycarbonate (GTTP) filters (Isopore, Merck, Germany) and air dried as described previously (64). Filters were mounted onto aluminum stubs with carbon tape and coated with $\sim 8-\mathrm{nm}$ Pt with a BalTec SCD 005 sputter coater (BalTec, Liechtenstein). The samples were examined with a Leo $1450 \mathrm{VP}$ (Zeiss, Germany) at $5 \mathrm{kV}$ and 5-mm working distance using an Everhart-Thornley secondary electron detector.

MPN enumerations of Fe-metabolizing bacteria. For enumeration of Fe-metabolizing microorganisms in summer 2014, sediment was sliced in 0.5-cm slices from 0 - to 3 -cm sediment depth. In February 2015, sediment was sliced in $1-\mathrm{cm}$ slices from 0 to $3 \mathrm{~cm}$, in $2-\mathrm{cm}$ slices from 3 to 7 $\mathrm{cm}$, and in a $3-\mathrm{cm}$ slice from 15 to $18 \mathrm{~cm}$. Each slice was homogenized and used for preparing a dilution series. Each tube of the dilution series contained $9 \mathrm{ml}$ nonamended ASW. The headspace was $\mathrm{N}_{2}: \mathrm{CO}_{2}$ (90:10). To the first tube of a dilution series, $1 \mathrm{~g}$ of sediment was added, and a $10 \times$ dilution series up to a dilution of $10^{-12}$ was prepared.

MPN enumerations of anaerobic bacteria were performed in 96-well deep-well plates (each well had a volume of $1 \mathrm{ml}$ ) with 7 replicates for each dilution. To prevent sulfate reduction, $2 \mathrm{mM} \mathrm{Na}_{2} \mathrm{MoO}_{4}$ was added to the 
medium. All work was done in an anoxic glove box $\left(\mathrm{N}_{2}\right.$ atmosphere). For the different types of microbial metabolism, different media were prepared. The medium for photoferrotrophs was amended with $10 \mathrm{mM}$ $\mathrm{FeCl}_{2}$ and filtered through a $0.22-\mu \mathrm{m}$ filter after $48 \mathrm{~h}$ to remove the $\mathrm{Fe}$ (II) minerals that formed with the phosphate and bicarbonate present in the medium. After filtration, the concentration of $\mathrm{Fe}(\mathrm{II})$ in the medium was approximately $6 \mathrm{mM}$, and the $\mathrm{PO}_{4}{ }^{3-}$ concentration was typically lowered to $40 \mu \mathrm{M}$ (65). For quantification of mixotrophic nitrate-reducing Fe(II) oxidizers, the $\mathrm{Fe}(\mathrm{II})$-containing medium was amended with $4 \mathrm{mM} \mathrm{NO}_{3}$ and $0.5 \mathrm{mM}$ acetate. For Fe(III)-reducing bacteria, the medium contained $5 \mathrm{mM}$ ferrihydrite, $5 \mathrm{mM}$ acetate, and $5 \mathrm{mM}$ lactate. To each well, $900 \mu \mathrm{l}$ of the respective medium was added, and then $100 \mu \mathrm{l}$ of the respective dilution of the sediment was added. Each dilution was inoculated into 7 wells, while 1 well served as a sterile control and remained uninoculated. For anoxic incubation, the Anaerocult system (Merck, Germany) was used, together with an $\mathrm{O}_{2}$ indicator stick (Merck, Germany). Incubation was done for 8 weeks at $20^{\circ} \mathrm{C}$ either in light for photoferrotrophs (the same light source as for enrichments) or in the dark for nitrate-reducing Fe(II) oxidizers and $\mathrm{Fe}(\mathrm{III})$ reducers. Evaluation of positive wells was done visually, as the rusty-orange $\mathrm{Fe}(\mathrm{III})$ minerals formed were easily detectable. To check, whether Fe(II) was oxidized by anoxygenic phototrophic Fe(II) oxidizers and not by oxygenic phototrophs, control experiments were performed in which MPN plates for photoferrotrophs were incubated in infrared (IR) light (wavelength $>730 \mathrm{~nm}$ ) by placing an IR bandpass filter (infrared filter 87; Lee, United Kingdom) between the MPN plates and a normal 40-W halogen light bulb (following references 66 and 67).

MPN enumerations for microaerophilic Fe(II) oxidizers were performed in gel-stabilized gradient tubes with a bottom layer containing $1 \%$ (wt/vol) agarose with a 1:1 mixture of FeS and ASW medium overlaid by ASW medium with $0.15 \%$ (wt $/ \mathrm{vol}$ ) agarose and air in the headspace (3, 68). These tubes provide opposing gradients of $\mathrm{Fe}(\mathrm{II})$ and $\mathrm{O}_{2}$ and thus optimal conditions for growth of microaerophilic Fe(II) oxidizers. Duplicate tubes were inoculated with $100 \mu$ l of the respective dilution. Control tubes remained uninoculated. Incubation was done at $20^{\circ} \mathrm{C}$ in the dark. Growth of microaerophilic Fe(II) oxidizers was evaluated visually by the formation of a distinct rusty-orange growth band and was confirmed by fluorescence microscopy and LIVE/DEAD staining. In order to confirm the results from gradient tubes, some experiments were performed in which the dilution series was inoculated into ZVI plates, where the presence of $\mathrm{Fe}$ (II) oxidizers was later evaluated by fluorescence microscopy and LIVE/DEAD staining (based on the presence of cells and twisted stalks).

For all MPN incubations, positive wells/tubes per dilution were counted, and the most probable number was calculated with the software Klee (69).

DNA extraction. From environmental samples, DNA was extracted from $0.25 \mathrm{~g}$ sediment with the PowerSoil DNA isolation kit (Mo Bio Laboratories Inc., Carlsbad, CA, USA). For the enrichment cultures, DNA was extracted from $1.8 \mathrm{ml}$ of the liquid cultures with the UltraClean Microbial DNA isolation kit (Mo Bio Laboratories Inc., Carlsbad, CA, USA) or with the PowerSoil DNA isolation kit (Mo Bio Laboratories Inc., Carlsbad, CA, USA) if DNA isolation with the UltraClean kit was not successful or DNA concentrations were too low.

qPCR for Zetaproteobacteria and total bacteria. To confirm the results of the MPN studies for microaerophilic Fe(II) oxidizers, a quantitative PCR (qPCR) for Zetaproteobacteria was performed. Copy numbers of 16S rRNA genes in the environmental DNA extracts were quantified on an iQ5 Real-Time PCR cycler (Bio-Rad Laboratories GmbH, Germany) using SsoAdvanced Universals SYBR Green Supermix (Bio-Rad). The primers Zeta672F (5'-CGGAATTCCGTGTGTAGCAGT-3') and Zeta837R (5'-GCCACWGYAGGGGTCGATACC-3') (36) were used at a concentration of $250 \mathrm{nM}$. In addition, reaction mixtures contained $5 \mu$ l SYBR green master mix, $1 \mu$ l of template (between 10 and 100 ng of DNA), and DNase-free water in a final volume of $10 \mu \mathrm{l}$. The qPCR program was as follows: $10 \mathrm{~min}$ at $95^{\circ} \mathrm{C}$, followed by 40 cycles of $15 \mathrm{~s}$ at $95^{\circ} \mathrm{C}$ and $60 \mathrm{~s}$ at $60^{\circ} \mathrm{C}$. At the end, a melting curve from 60 to $99^{\circ} \mathrm{C}$ (in $0.5^{\circ} \mathrm{C}$ steps) was recorded.

To be able to calculate the percentages of $\mathrm{Fe}$ (II) oxidizers and $\mathrm{Fe}$ (III) reducers relative to the total bacterial community, qPCR for total bacteria was done using DNA extracts from sediment samples. The same cycler and master mix as for the Zetaproteobacteria $\mathrm{qPCR}$ was used. The primers 341F ( $5^{\prime}$-CCTACGGGAGGCAGCAG-3') (70) and 797R (5' -GGACTAC CAGGGTATCTAATCCTGTT- $3^{\prime}$ ) (71) were used at concentrations of 75 and $225 \mathrm{nM}$, respectively. The reaction mixture further contained $5 \mu \mathrm{l}$ SYBR green master mix, $1 \mu \mathrm{l}$ of template, and DNase-free water in a final volume of $10 \mu \mathrm{l}$. The $\mathrm{qPCR}$ program was as follows: $2 \mathrm{~min}$ at $98^{\circ} \mathrm{C}$, followed by 40 cycles of $98^{\circ} \mathrm{C}$ for $5 \mathrm{~s}$ and $60^{\circ} \mathrm{C}$ for $12 \mathrm{~s}$. The thermal program was completed by a melting curve from 60 to $99^{\circ} \mathrm{C}$ (in $0.5^{\circ} \mathrm{C}$ steps).

After $\mathrm{qPCR}, 2 \%$ agarose gels were run with the $\mathrm{qPCR}$ products to ensure amplification specificity and that the amplicons had the expected length. Cell numbers per gram dry sediment were calculated from the qPCR 16S rRNA gene copy numbers, considering the average rRNA operon numbers of the respective taxa for bacteria as listed in the rRNA Operon Copy Number Database (http://rrndb.mmg.msu.edu/index .php). For Zetaproteobacteria, a 16S rRNA gene copy number of 2 was assumed, according to Kato et al. (36).

Phylogenetic affiliation of enrichment cultures; DGGE, sequencing, and sequence analysis. A PCR to obtain $16 \mathrm{~S}$ rRNA gene fragments from the enrichment cultures for denaturing gradient gel electrophoresis (DGGE) (70) was performed with the general bacterial 16S rRNA gene group-specific primers 341GC F (70) and 907R (72). Depending on the concentration of the PCR product, 5 to $20 \mu l$ was loaded on an acrylamide gel with a urea gradient ranging from $35 \%$ at the top to $60 \%$ at the bottom of the gel. After $16 \mathrm{~h}$ of electrophoresis, the gel was stained with ethidium bromide. Under UV light, the most prominent bands were excised from the DGGE gel, diluted with $200 \mu \mathrm{l}$ water, and incubated for $2 \mathrm{~h}$ at $4^{\circ} \mathrm{C}$. After this incubation, a PCR was run with the primers $341 \mathrm{~F}$ and $907 \mathrm{R}$, with the same PCR program as for the DGGE. The resulting PCR products were loaded on a $1 \%$ agarose gel, and the bands were excised and cleaned with the Wizard PCR cleanup system (Promega Laboratories, WI) and cloned using a Qiagen PCR cloning kit (Qiagen, Germany). Vectors were transformed into competent cells (Escherichia coli DH5 $\alpha$ ) and plated onto LB medium containing ampicillin, isopropyl- $\beta$-D-thiogalactopyranoside (IPTG), and X-Gal (5-bromo-4-chloro-3-indolyl- $\beta$-D-galactopyranoside) for blue/white screening. White colonies were picked and tested for the correct insert size. Overnight cultures were prepared from colonies with the correct inserts in $5 \mathrm{ml}$ liquid LB medium containing ampicillin. Plasmid DNA was isolated from these cultures and sent to GATC Biotech (Constance, Germany) for sequencing. For each band excised from the DGGE gel, at least three clones were picked and sequenced. The resulting sequences were trimmed using the software program Geneious R6 (Biomatters). Then, $16 \mathrm{~S}$ rRNA gene sequences were identified and classified using the Basic Local Alignment Search Tool (BLAST) (73).

Nucleotide sequence accession numbers. Sequences for enrichment culture clones of the $\mathrm{Fe}$ (II) oxidizers and Fe(III) reducers were deposited in the ENA and GenBank databases under accession numbers LN986435 to LN986485 (see Table S2 in the supplemental material).

\section{RESULTS}

Characterization of sediments. The results of sediment analyses and geochemical measurements for both field sites, Norsminde Fjord and Kalø Vig, from summer 2014 are shown in Table 1 and Fig. 1 . The sediments were visually very different. Sediment from Norsminde Fjord was fine grained and muddy. Its color was brownish for approximately the upper $0.5 \mathrm{~cm}$, suggesting oxidized conditions. Below $0.5 \mathrm{~cm}$, the sediment was dark and blackish, suggesting the presence of FeS (see Fig. S1 in the supplemental material for an image of the core). The water content of Norsminde Fjord sediment was $80 \%$ by weight ( 80 weight $\%$ ) in the top $0.5 \mathrm{~cm}$ and $75 \%$ below that. The sediment TOC was $3.31 \pm 0.42$ 
TABLE 1 Geochemical parameters of sediments and water from the two field sites, Norsminde Fjord and Kalø Vig, Aarhus Bay, Denmark

\begin{tabular}{lll}
\hline & Value \\
\cline { 2 - 3 } Parameter $^{a}$ & Norsminde Fjord & Kalø Vig \\
\hline Water content by wt $(\%)^{\text {DOC water column }\left(\mathrm{mg} \mathrm{liter}^{-1}\right)}$ & $71 \pm 3$ & $19 \pm 4$ \\
DOC porewater $\left(\mathrm{mg} \mathrm{liter}^{-1}\right)$ & $8.28 \pm 0.06$ & $4.21 \pm 0.09$ \\
TOC sediment $(\%)$ & $3.31 \pm 0.42$ & $6.56 \pm 0.06$ \\
Pore water $\mathrm{NO}_{3}{ }^{-}(\mu \mathrm{M})$ & $18.3 \pm 8.2$ & $0.38 \pm 0.05$ \\
Pore water $\mathrm{NO}_{2}{ }^{-}(\mu \mathrm{M})$ & $\mathrm{BDL}^{b}$ & $4.2 \pm 2.4$ \\
water column $\mathrm{pH}$ & 7.9 & $\mathrm{BDL}$ \\
Water column $\mathrm{O}_{2}$ saturation $(\%)$ & 100 & 8.1 \\
Fe(II) in pore water $(\mu \mathrm{M})$ & $104 \pm 64$ & 100 \\
\hline
\end{tabular}

${ }^{a}$ All parameters were determined in summer 2014.

${ }^{b} \mathrm{BDL}$, below detection limit.

weight $\%$, and DOC in the pore water was $8.24 \pm 0.12 \mathrm{mg} \mathrm{liter}^{-1}$. In contrast, sediment from Kalø Vig had a larger grain size and a brighter color. It was light brown in the uppermost $2 \mathrm{~mm}$. Below this presumed oxidized layer, a 1- to 2-mm-thick purple layer was found, suggesting the presence of anoxygenic phototrophic bacteria. Below the purple layer, the sediment was grayish, again indicating the presence of FeS (see Fig. S1 in the supplemental material for an image of the core). The purple layer and the grayish color of the sediment were observed only in summer. In winter, the sediment was a light-brown color throughout the sampled depth. The water content of Kalø Vig sediment was $40 \%$ in the top $0.5 \mathrm{~cm}$ of the sediment and $18 \%$ below that. The TOC of the sediment was $0.38 \pm 0.05$ weight $\%$, and the DOC in the pore water was $6.56 \pm 0.06 \mathrm{mg} \mathrm{liter}^{-1}$. The concentrations of nitrate in the pore water of both sediments were very low, $<20 \mu \mathrm{M}$ (Table 1 ), and nitrate was present only in the upper $3 \mathrm{~mm}$. The Fe(II) concentrations in Norsminde Fjord sediment were up to $207 \pm$ 22.21 $\mu \mathrm{mol}$ per g dry sediment in $6 \mathrm{M} \mathrm{HCl}$ extractions and thus about 10 times higher than in Kalø Vig sediments, where only a maximum of $21 \pm 2.42 \mu \mathrm{mol} F($ II) per g dry sediment could be extracted with $6 \mathrm{M} \mathrm{HCl}$ (Fig. 2). Pore water concentrations of $\mathrm{Fe}(\mathrm{II})$ were also higher in Norsminde Fjord sediment $(104 \pm 64$ $\mu \mathrm{M})$ than in Kalø Vig sediment $(70 \pm 52 \mu \mathrm{M})$. Light penetrated
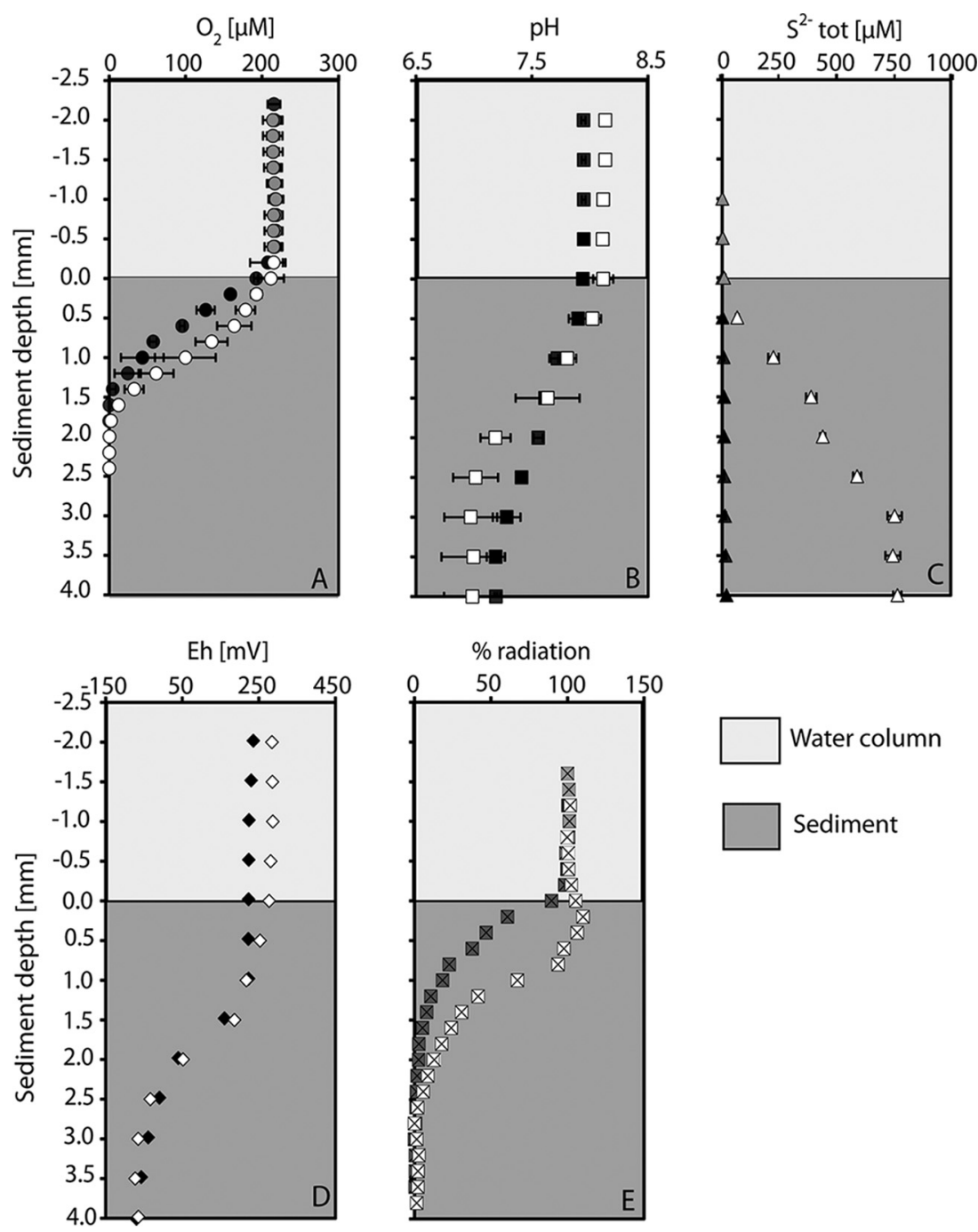

FIG 1 Microsensor data from summer 2014 for sediment from Norsminde Fjord (black symbols) and Kalø Vig (white symbols). (A) Oxygen. (B) pH. (C) Total sulfide. (D) Redox potential. (E) Scalar irradiance. The error bars indicate standard deviations. 
$0.5 \mathrm{M} \mathrm{HCl}$

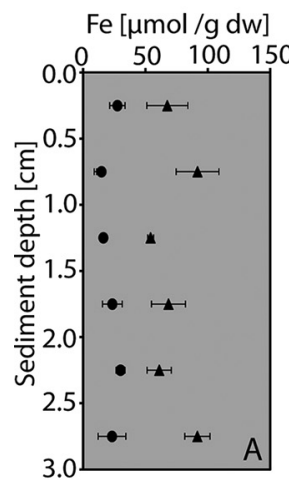

$6 \mathrm{M} \mathrm{HCl}$

$\mathrm{Fe}[\mu \mathrm{mol} / \mathrm{g} \mathrm{dw}]$

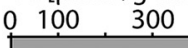

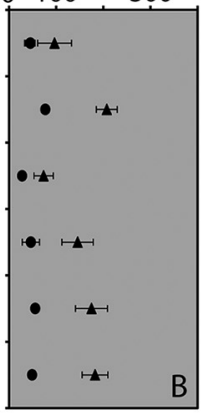

$0.5 \mathrm{M} \mathrm{HCl}$

Fe $[\mu \mathrm{mol} / \mathrm{g} \mathrm{dw}]$

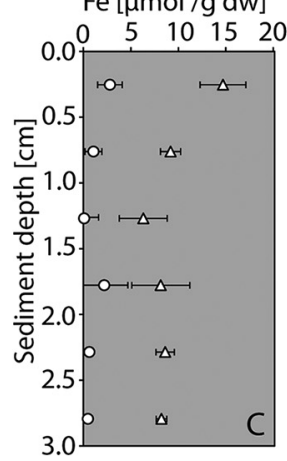

$6 \mathrm{M} \mathrm{HCl}$

$\mathrm{Fe}[\mu \mathrm{mol} / \mathrm{g} \mathrm{dw}]$
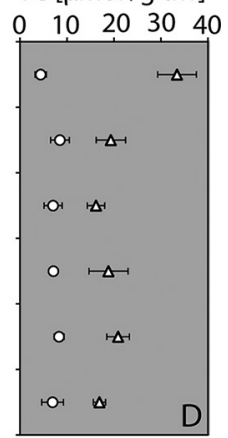

FIG 2 Sedimentary Fe content determined by sequential Fe extractions given in micromoles of Fe extracted per gram dry sediment (dw, dry weight) with $0.5 \mathrm{M}$ $\mathrm{HCl}$ ( $\mathrm{A}$ and $\mathrm{C}$ ) and $6 \mathrm{M} \mathrm{HCl}$ (B and D). The black symbols show data for Norsminde Fjord and the white symbols for Kalø Vig. Triangles, Fe(II); circles, Fe(III). The sediment for these measurements was sampled in summer 2014. The error bars indicate standard deviations.

more deeply into the sandy sediment of Kalø Vig (3-mm penetration depth) than into the Norsminde Fjord sediment (2-mm penetration depth) (Fig. 1).

The Kalø Vig site was primarily barren sand with patches of sea grass (Zostera spp.) and brown algae (Fucus spp.). Roots of seagrass occasionally were found in the sediment cores. At both field sites, the presence of bioturbating/bioirrigating fauna was observed but not quantified (mainly different bristle worms-Nereis spp. at Norsminde Fjord and Arenicola sp. at Kalø Vig-together with different crustaceans). The abundance of burrows of Arenicola at the Kalø Vig site can be seen in Fig. S2 in the supplemental material.

Oxygen, pH, sulfide, redox potential, and scalar irradiance. Microelectrode profiles revealed that oxygen penetrated less than $2 \mathrm{~mm}$ in both sediments. The pHs in the water column were 7.9 and 8.1 for Norsminde Fjord and Kalø Vig, respectively, decreasing to 7.1 along the depth gradient in both sediments. Sulfide was not detectable in pore water of Norsminde Fjord sediment. In Kalø Vig sediment, sulfide was detected in the pore water already at $0.5 \mathrm{~mm}$ sediment depth with a concentration of $65 \mu \mathrm{M}$ and increased to a maximum of $750 \mu \mathrm{M}$ at 3-mm sediment depth. Measurements with redox microelectrodes showed that in both cases the redox potential was positive in the water column and in the pore water of the oxygenated layer of the sediment $(+235 \mathrm{mV}$ and $+285 \mathrm{mV}$ for Norsminde Fjord and Kalø Vig sediments, respectively). As soon as the anoxic part of the pore water was reached, the redox potential decreased to $-65 \mathrm{mV}$ and $-75 \mathrm{mV}$ for Norsminde Fjord and Kalø Vig sediments, respectively (Fig. 1). Interestingly, light penetrated deeper than oxygen in both sediments during our summer sampling campaign. This was different in winter, when oxygen penetrated much deeper than light (5 to 6 $\mathrm{mm}$ ) (data not shown).

Depth distribution of $\mathrm{Fe}$ (II)-oxidizing and $\mathrm{Fe}(\mathrm{III})$-reducing bacteria. Depth profiles of viable counts for Fe(II) oxidizers and $\mathrm{Fe}$ (III) reducers determined by the MPN method in sediments that were collected in summer 2014 are shown in Fig. 3. Surprisingly, the abundances of the different Fe metabolizers did not change significantly with depth throughout the upper $3 \mathrm{~cm}$ of the sediment. In a further MPN enumeration in February 2015, where viable counts were made at 0 - to 3-, 3- to 7-, and 15- to $18-\mathrm{cm}$ sediment depths, similar cell numbers were found over the entire depth interval. Cell numbers were highest in the organic-rich Norsminde Fjord, except for photoferrotrophs, which were most prominent at the sandy Kalø Vig (Fig. 3). The lowest cell numbers were found for photoferrotrophs, which at different sediment depths reached from $1.5 \times 10^{2}$ to $3.1 \times 10^{2}$ cells per $g$ (dry weight) for Norsminde Fjord and $2.92 \times 10^{1}$ to $7.7 \times 10^{1}$ cells $^{-1}$ (dry weight) for Kalø Vig sediment. MPNs for photoferrotrophs in full-spectrum light and in IR light alone yielded comparable cell numbers, demonstrating that the observed Fe(II) oxidation indeed stemmed from phototrophic Fe(II) oxidizers and was not caused by $\mathrm{O}_{2}$ produced by cyanobacteria (data not shown). Nitrate-reducing $\mathrm{Fe}(\mathrm{II})$ oxidizers had abundances of $7.9 \times 10^{3}$ to $3.5 \times 10^{4}$ cells $^{-1}$ (dry weight) in Norsminde Fjord and $6.6 \times$ $10^{2}$ to $7.7 \times 10^{3}$ cells $\mathrm{g}^{-1}$ (dry weight) in Kalø Vig sediments. Among all Fe-metabolizing microorganisms, the highest cell numbers were found for microaerophilic Fe(II) oxidizers. Both cultivation-based methods used for quantifying microaerophilic $\mathrm{Fe}(\mathrm{II})$ oxidizers, i.e., the gradient tubes and ZVI plates, showed comparable results (data for ZVI plates are not shown). The cell numbers of microaerophilic $\mathrm{Fe}(\mathrm{II})$ oxidizers determined by the gradient tube method were $1.4 \times 10^{5}$ to $1.0 \times 10^{6}$ cells g $^{-1}$ (dry weight) for Norsminde Fjord and $2.1 \times 10^{3}$ to $2.4 \times 10^{4}$ cells g $^{-1}$ (dry weight) for Kalø Vig. Cell numbers of Fe(III) reducers ranged from $1.1 \times 10^{3}$ to $4.4 \times 10^{4}$ cells $^{-1}$ (dry weight) in Norsminde

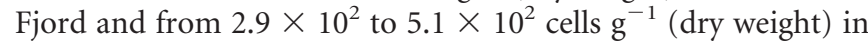
Kalø Vig sediments. The total bacterial cell numbers determined by qPCR were $2.87 \times 10^{9}\left( \pm 2.27 \times 10^{9}\right)$ to $5.77 \times 10^{10}( \pm 4.48 \times$ $10^{10}$ ) cells $\mathrm{g}^{-1}$ (dry weight) for Norsminde Fjord sediment and $2.12 \times 10^{8}\left( \pm 1.89 \times 10^{8}\right)$ to $8.16 \times 10^{9}\left( \pm 3.34 \times 10^{9}\right)$ cells $^{-1}$ (dry weight) for Kalø Vig sediment (see Table S1 in the supplemental material).

Zetaproteobacteria. The cell numbers of Zetaproteobacteria determined by qPCR for Norsminde Fjord sediment $\left(1.95 \times 10^{6}\right.$ to $3.21 \times 10^{6}$ cells g $^{-1}$ [dry weight]) were only slightly higher than the MPNs, while for Kalø Vig, the cell numbers determined by qPCR $\left(2.03 \times 10^{5}\right.$ to $7.35 \times 10^{5}$ cells g $^{-1}$ [dry weight] $)$ were higher by up to 2 orders of magnitude (Fig. 4). Neither MPN nor qPCR cell numbers changed significantly with depth.

Enrichment cultures of microaerophilic Fe(II) oxidizers. Enrichment cultures for microaerophilic Fe(II) oxidizers on ZVI plates from both field sites showed $\mathrm{Fe}$ (II) oxidation and growth of 

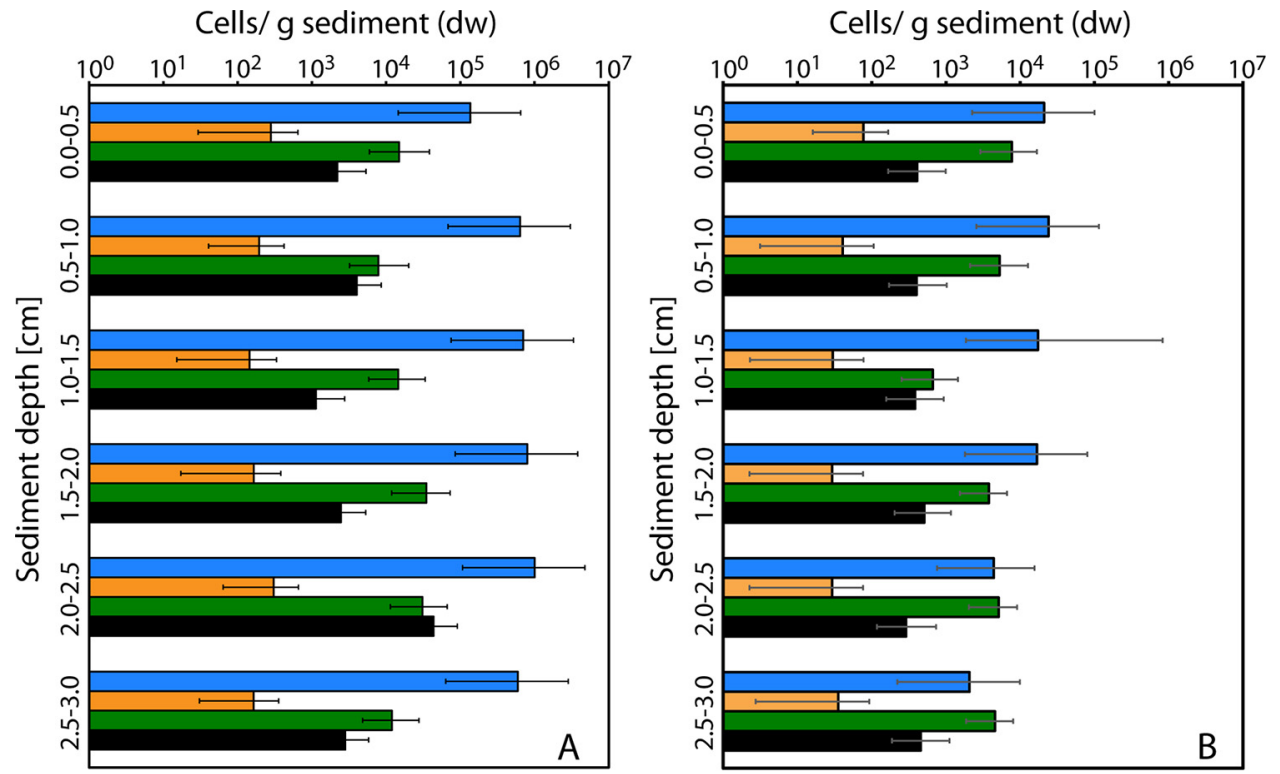

FIG 3 MPN counts of Fe(II)-oxidizing and Fe(III)-reducing microorganisms over sediment depth for Norsminde Fjord (A) and Kalø Vig (B). Blue bars, microaerophilic Fe(II) oxidizers; orange bars, photoferrotrophs; green bars, nitrate-reducing Fe(II) oxidizers (mixotrophic); black bars, Fe(III)-reducing bacteria. The sediment for MPN incubations was sampled in summer 2014. The error bars indicate standard deviations.

cells already after 2 to 3 days, as indicated by large numbers of twisted stalks visible under the light microscope (Fig. 5). After 3 or 4 transfers from dilution-to-extinction series, the microaerophilic enrichments from both field sites showed homogeneous cell mor-

\section{Cells/g sediment $(\mathrm{dw})$}

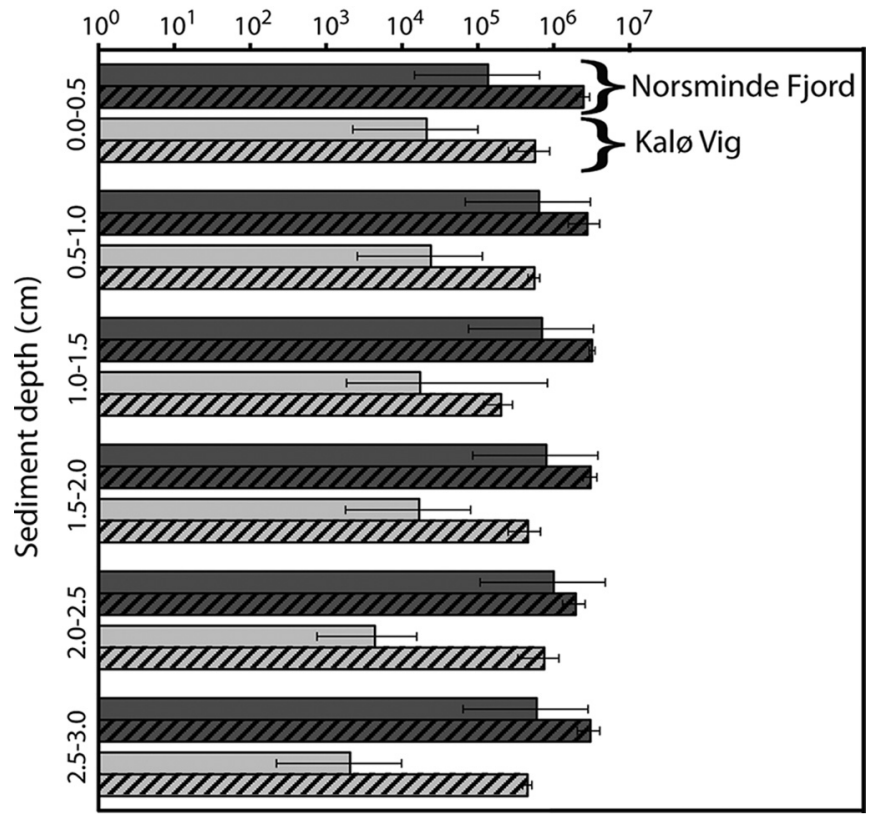

FIG 4 Comparison of cell numbers found by MPNs for microaerophilic $\mathrm{Fe}$ (II) oxidizers from Norsminde Fjord (dark-gray bars) and Kalø Vig (lightgray bars) and qPCR data for Zetaproteobacteria from Norsminde Fjord (darkgray hatched bars) and Kalø Vig (light-gray hatched bars). Cell numbers were calculated from qPCR-based 16S rRNA gene copy numbers using a correction of 2 gene copies per cell, according to the method of Kato et al. (36). Sediment for these analyses was sampled in summer 2014. The error bars indicate standard deviations. phologies (Fig. 5). Microscopic analyses showed that some cells were attached to stalks while others were motile, as described previously (74). Motile cells were found in lower dilutions and cultures that were grown for a longer time ( $>7$ days). In the microaerophilic $\mathrm{Fe}(\mathrm{II})$-oxidizing enrichment cultures from both field sites, the cells were rod and bean shaped (ca. $1 \mu \mathrm{m}$ long and $0.4 \mu \mathrm{m}$ wide). For each enrichment culture from the two field sites, two distinct bands were found on the DGGE gel and excised. After sequencing, the phylogenetic investigation showed that all the sequences of the enrichment cultures from both field sites belonged to the class Zetaproteobacteria. All the sequenced clones ( 6 for each field site) had $98 \%$ sequence similarity to Mariprofundus sp. strain M34. The sequenced clones were $99.7 \%$ and $99.6 \%$ identical to each other for the microaerophilic Norsminde Fjord and Kalø Vig enrichments, respectively. The sequences were uploaded to the ENA database and accession numbers are shown in Table S2 in the supplemental material. No heterotrophic growth was observed on R2A-ASW plates.

Enrichment cultures of phototrophic $\mathrm{Fe}(\mathrm{II})$ oxidizers. Enrichment cultures from both field sites incubated with $\mathrm{Fe}$ (II) amendment under anoxic conditions in the light showed the first rusty patches after 4 to 5 weeks, indicating activity of phototrophic $\mathrm{Fe}(\mathrm{II})$ oxidizers. The presence of cells was confirmed by fluorescence microscopy, and the highest dilution showing the presence of cells and $\mathrm{Fe}(\mathrm{II})$ oxidation was subjected to a further dilution series. After transfer through more than 10 dilution series, cell morphologies in the enrichments from Norsminde Fjord were very homogeneous. Cells in Norsminde Fjord enrichments were small and rod shaped ( 1.5 to $1.8 \mu \mathrm{m}$ long and 0.5 to $0.6 \mu \mathrm{m}$ wide) (Fig. 5). In the enrichment from Kalø Vig, in which cells were growing much more slowly, two distinct morphologies were observed after nine dilution series, namely, short (ca. 1- $\mu \mathrm{m}$-long and 0.2 - to $0.3-\mu \mathrm{m}$-wide) and long (ca. 2- to 3- $\mu \mathrm{m}$-long and $0.5-\mu \mathrm{m}$ wide) rod-shaped cells (Fig. 5). Both enrichment cultures oxidized $\mathrm{Fe}$ (II) in infrared light (wavelength $>730 \mathrm{~nm}$ ) (data not shown) 

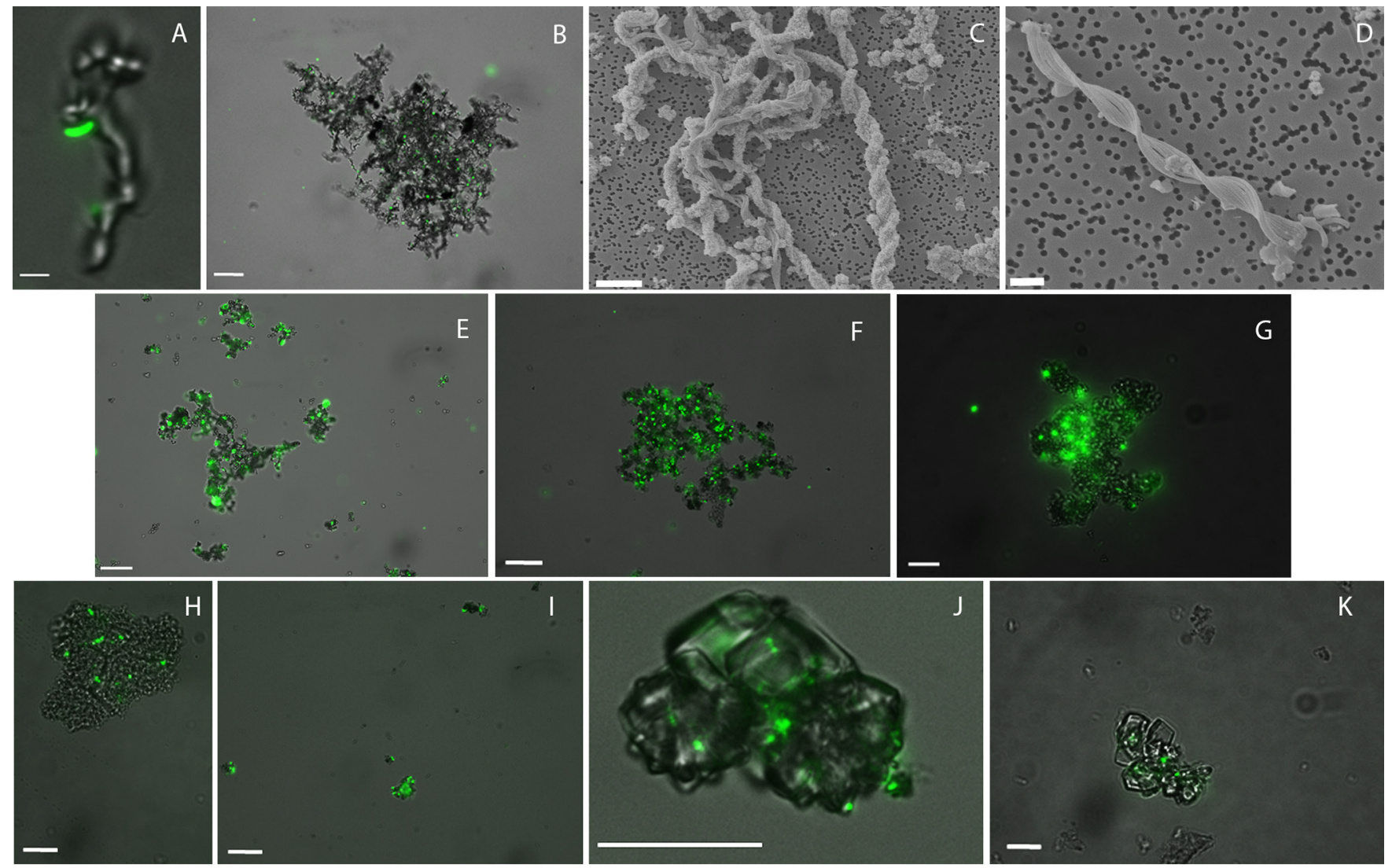

FIG 5 Fluorescence microscopy (A, B, and E to K) and scanning electron microscopy (C and D) images of the Fe(II) oxidizers and Fe(III) reducers enriched from sediments from Aarhus Bay. (A, D, and E) Microaerophilic enrichments from Norsminde Fjord. (B and C) Microaerophilic enrichments from Kalø Vig. (F) Photoferrotrophic enrichment from Norsminde Fjord. (G) Photoferrotrophic enrichment from Kalø Vig. (H and I) Nitrate-reducing Fe(II)-oxidizing enrichments from Norsminde Fjord and Kalø Vig, respectively. (J and K) Fe(III)-reducing enrichments from Kalø Vig and Norsminde Fjord, respectively. Scale bars, $25 \mu \mathrm{m}(\mathrm{B}, \mathrm{E}, \mathrm{F}$, and $\mathrm{H}$ to $\mathrm{K}), 1 \mu \mathrm{m}$ (A and D), $3 \mu \mathrm{m}(\mathrm{C})$, and $10 \mu \mathrm{m}(\mathrm{G})$.

at rates similar to those under full-spectrum light, indicating that anoxygenic photosynthesis was responsible for $\mathrm{Fe}(\mathrm{II})$ oxidation $(66,67)$. For the anoxygenic phototrophic Fe(II)-oxidizing enrichment from Norsminde Fjord, three distinct bands were identified on the DGGE gel. All the bands were excised and sequenced. All the sequences (a total of 9 ) of the enrichment from Norsminde Fjord had $99 \%$ sequence similarity to that of Chlorobium luteolum. The 9 sequences of the Norsminde Fjord photoferrotroph were 99.6\% identical to each other. For the Kalø Vig enrichment, two distinct bands were identified on the DGGE gel, and both bands were excised. The sequences of the enrichment from Kalø Vig confirmed the microscopic investigation showing that different species were present. The sequences were found to be $99 \%$ homologous to that of Rhodobacter sp. strain SW2 (2 of 6 sequences) or $98 \%$ homologous to that of Marichromatium purpuratum (4 of 6 sequences). The sequences were uploaded to the ENA database, and accession numbers are shown in Table S2 in the supplemental material. Detailed results and information on the physiological characteristics of the identified closest relatives are shown in Table 2.

Enrichment cultures of nitrate-reducing $\mathrm{Fe}(\mathrm{II})$ oxidizers. Within 1 week of incubation of sediments from both field sites in medium either amended with $\mathrm{Fe}(\mathrm{II})$, nitrate, and acetate or amended with $\mathrm{Fe}$ (II) and nitrate, a color change of the $\mathrm{Fe}(\mathrm{II})$ containing medium (from grayish-blue to orange) was ob- served, indicating the growth and activity of nitrate-reducing $\mathrm{Fe}$ (II) oxidizers. The presence of cells was confirmed by fluorescence microscopy, and the highest dilution showing growth or $\mathrm{Fe}(\mathrm{II})$ oxidation was subjected to a further dilution series. For enrichments from both field sites, growth was not observed after 3 or 4 transfers in dilution series to which no acetate was added, although growth initially was as fast as in the enrichments to which acetate was added. The enrichments to which acetate was added showed continuous Fe(II) oxidation and growth over more than 10 dilution series. Therefore, only the enrichments to which acetate was added were further transferred so that all enrichment cultures that remained were mixotrophic nitrate-reducing Fe(II) oxidizers. For enrichments from both field sites, cell morphologies after several transfers in enrichments containing nitrate, $\mathrm{Fe}$ (II), and acetate were homogeneous. Fluorescence microscopy showed that cells were closely associated with Fe minerals and also appeared to be located within the minerals. The cells from the enrichments from Norsminde Fjord appeared to be slightly larger (ca. 2.5 to $3 \mu \mathrm{m}$ long and $0.5 \mu \mathrm{m}$ wide) than the cells in enrichments from Kalø Vig (ca. $2 \mu \mathrm{m}$ long and 0.5 $\mu \mathrm{m}$ wide). Both were rod-shaped cells (Fig. 5). On the DGGE gel, two distinct bands were found for both enrichments. Both bands were excised, and sequence analysis revealed that the sequences of the enrichment from Norsminde Fjord had 99\% sequence simi- 
TABLE 2 Identification of sequences from DGGE bands of enrichment cultures and physiological characteristics of closest relatives

\begin{tabular}{|c|c|c|c|c|}
\hline Name and sampling site & $\begin{array}{l}\text { Enrichment medium and } \\
\text { technique }\end{array}$ & Characteristics and morphology & $\begin{array}{l}\text { Closest cultured } \\
\text { relative and origin of } \\
\text { relative }\end{array}$ & $\begin{array}{l}\text { Closest known relative able to } \\
\text { oxidize/reduce Fe }\end{array}$ \\
\hline $\begin{array}{l}\text { Microaerophilic Fe(II) } \\
\text { oxidizer S1 Oct. c; } \\
\text { Norsminde Fjord }\end{array}$ & $\begin{array}{l}\text { ZVI plates with ASW; } \\
\text { dilution to extinction }\end{array}$ & $\begin{array}{l}\text { Bean-shaped cells ca. } 0.4 \mu \mathrm{m} \text { wide and } \\
1 \mu \mathrm{m} \text { long; makes filigree stalks } \\
\text { with several filaments; motile }\end{array}$ & $\begin{array}{l}\text { Mariprofundus sp. M34 } \\
\text { (98\% sequence } \\
\text { similarity); isolated } \\
\text { from an iron mat at } \\
\text { Loihi Seamount } \\
\text { (HI) (76) }\end{array}$ & $\begin{array}{l}\text { Mariprofundus sp. M34 (98\% } \\
\text { sequence similarity); isolated } \\
\text { from an iron mat at Loihi } \\
\text { Seamount (HI) (76) }\end{array}$ \\
\hline $\begin{array}{l}\text { Photoferrotroph S1.1; } \\
\text { Norsminde Fjord }\end{array}$ & $\begin{array}{l}\text { ASW with } \mathrm{Fe}(\mathrm{II}) \text { in light; } \\
\text { dilution to extinction }\end{array}$ & $\begin{array}{l}\text { Rod-shaped cells ca. } 0.5-0.6 \mu \mathrm{m} \text { wide } \\
\text { and } 1.6-1.5 \mu \mathrm{m} \text { long; closely } \\
\text { associated with iron minerals; can } \\
\text { also grow photolithotrophically } \\
\text { with hydrogen or } \\
\text { photoheterotrophically with } \\
\text { organic acids like lactate }\end{array}$ & $\begin{array}{l}\text { C. luteolum }(99 \% \\
\text { sequence similarity); } \\
\text { isolated from a } \\
\text { freshwater ditch } \\
\text { close to the river } \\
\text { Rhine }(100,111)\end{array}$ & $\begin{array}{l}\text { C. ferrooxidans KoFox ( } 93 \% \\
\text { sequence similarity); isolated } \\
\text { from a freshwater ditch close } \\
\text { to Constance ( } 24)\end{array}$ \\
\hline $\begin{array}{l}\text { Photoferrotroph S2.2; } \\
\text { Kalø Vig }\end{array}$ & $\begin{array}{l}\text { ASW with } \mathrm{Fe}(\mathrm{II}) \text { in light; } \\
\text { dilution to extinction }\end{array}$ & $\begin{array}{l}\text { Two different morphotypes: smaller } \\
\text { rod-shaped cells ca. } 0.2-0.3 \mu \mathrm{m} \\
\text { wide and } 1 \mu \mathrm{m} \text { long and larger rod- } \\
\text { shaped cells } 0.5 \mu \mathrm{m} \text { wide and } 2-3 \\
\mu \mathrm{m} \text { long; closely associated with } \\
\text { iron minerals; can also grow aerobic } \\
\text { on R2A ASW-agar plates, where red } \\
\text { and yellow colonies form }\end{array}$ & $\begin{array}{l}\text { Rhodobacter sp. SW2 } \\
\quad \text { ( } 99 \% \text { sequence } \\
\text { similarity); isolated } \\
\text { from a freshwater } \\
\text { pond close to } \\
\text { Hannover (5) } \\
\text { M. purpuratum ( } 98 \% \\
\text { sequence similarity); } \\
\text { isolated from a } \\
\text { marine sponge (112) }\end{array}$ & $\begin{array}{l}\text { Rhodobacter sp. SW2 ( } 84 \% \\
\text { sequence similarity) }\end{array}$ \\
\hline $\begin{array}{l}\mathrm{Fe}(\mathrm{III}) \text { reducer } \mathrm{S} 1.3 \text {; } \\
\text { Norsminde Fjord }\end{array}$ & $\begin{array}{l}\text { ASW with } \mathrm{Fe}(\mathrm{III}) \text {, acetate, } \\
\text { and lactate; dilution to } \\
\text { extinction }\end{array}$ & $\begin{array}{l}\text { Rod-shaped cells ca. } 0.5 \mu \mathrm{m} \text { wide and } \\
2 \mu \mathrm{m} \text { long; grow associated with } \\
\text { iron minerals }\end{array}$ & $\begin{array}{l}\text { S. colwelliana ( } 99 \% \\
\text { sequence similarity); } \\
\text { isolated from an } \\
\text { estuarine } \\
\text { aquaculture of } \\
\text { oysters (111) }\end{array}$ & $\begin{array}{l}\text { S. colwelliana ( } 99 \% \text { sequence } \\
\text { similarity); isolated from an } \\
\text { estuarine aquaculture of } \\
\text { oysters (111) }\end{array}$ \\
\hline $\begin{array}{l}\text { Fe(III) reducer S2.3; } \\
\text { Kalø Vig }\end{array}$ & $\begin{array}{l}\text { ASW with } \mathrm{Fe}(\mathrm{III}) \text {, acetate, } \\
\text { and lactate; dilution to } \\
\text { extinction }\end{array}$ & $\begin{array}{l}\text { Rod-shaped cells ca. } 0.5 \mu \mathrm{m} \text { wide and } \\
2 \mu \mathrm{m} \text { long; grow associated with } \\
\text { iron minerals }\end{array}$ & $\begin{array}{l}\text { S. colwelliana ( } 99 \% \\
\text { sequence similarity); } \\
\text { isolated from an } \\
\text { estuarine } \\
\text { aquaculture of } \\
\text { oysters (115) }\end{array}$ & $\begin{array}{l}\text { S. colwelliana ( } 99 \% \text { sequence } \\
\text { similarity); isolated from an } \\
\text { estuarine aquaculture of } \\
\text { oysters (115) }\end{array}$ \\
\hline
\end{tabular}

larity to that of Hoeflea marina (6 sequences). For the enrichment from Kalø Vig, it was found that the sequences had $99 \%$ sequence similarity to that of Denitromonas indolicum strain MPKc (6 sequences). The sequenced clones from the Nors- minde Fjord and the Kalø Vig enrichments were 99.0\% and $99.6 \%$ similar to each other. The sequences were uploaded to the ENA database, and accession numbers are shown in Table $\mathrm{S} 2$ in the supplemental material. 
Enrichment cultures of $\mathrm{Fe}(\mathrm{III})$ reducers. Within 10 days, a color change from orange to dark brown to blackish was observed in enrichments from both field sites amended with $\mathrm{Fe}(\mathrm{III})$ oxyhydroxide ferrihydrite as the electron acceptor, suggesting microbial $\mathrm{Fe}(\mathrm{III})$ reduction. Growth was investigated by fluorescence microscopy, and the highest dilution showing growth (color change and cells) was subjected to a further dilution series. After 5 such dilution-to-extinction series, cell morphologies were homogeneous. There were no visible differences in cell morphologies between the enrichments from the two field sites. In both cases, the cells were rod shaped (ca. $2 \mu \mathrm{m}$ long and $0.5 \mu \mathrm{m}$ wide) and closely associated with the Fe minerals (Fig. 5). On the DGGE gel, two distinct bands were found for both enrichments. All the bands were excised from the gel, and the two enrichment cultures were found to be phylogenetically identical. All sequences from both enrichments had $99 \%$ sequence similarity to that of Shewanella colwelliana (6 sequences of each of the enrichments). The sequences of the clones from the Norsminde Fjord were 99.7\% similar to each other, and those from Kalø Vig were $99.5 \%$ similar to each other. The sequences were uploaded to the ENA database, and accession numbers are shown in Table S2 in the supplemental material.

\section{DISCUSSION}

Coexistence of different physiological types of $\mathrm{Fe}$ (II) oxidizers. Based on typical geochemical characteristics of marine sediments, it can be expected that autotrophic microaerophilic and nitratereducing $\mathrm{Fe}(\mathrm{II})$ oxidizers are widely distributed in marine sediments while phototrophic $\mathrm{Fe}(\mathrm{II})$ oxidizers are probably restricted to shallow coastal sediments, where sunlight reaches sediments that contain significant amounts of $\mathrm{Fe}(\mathrm{II})(47,50,51)$. This is why we conducted our study in shallow coastal sediments, where we expected the possible coexistence of all three types of $\mathrm{Fe}(\mathrm{II})$ oxidizers. Geochemical analysis of the two sediments studied here suggested that they could potentially harbor microaerophilic, nitrate-reducing, and anoxygenic phototrophic $\mathrm{Fe}(\mathrm{II})$-oxidizing bacteria. MPN enumerations and enrichment cultures indeed showed that all three types of $\mathrm{Fe}(\mathrm{II})$ oxidizers, and even $\mathrm{Fe}(\mathrm{III})$ reducers, coexist in these two typical but geochemically distinct marine sediments. This suggests that in both sediments the prerequisites for a complete biogeochemical Fe cycle, as described by Schmidt et al. (52), are present. This is the first time that the coexistence of all three metabolic types of $\mathrm{Fe}(\mathrm{II})$ oxidizers in the same habitat has been demonstrated, and we even identified members of these groups in enrichment cultures (see below). Marine microaerophilic Fe(II) oxidizers have so far been isolated only from deep-sea hydrothermal-vent systems or other marine habitats with elevated $\mathrm{Fe}$ (II) concentrations $(18,38,75,76)$. Marine photoferrotrophs have been isolated from only one field site, i.e., a tidal mud flat in the German Wadden Sea by Straub et al. (43). So far, only two marine cultures of nitrate-reducing $\mathrm{Fe}(\mathrm{II})$ oxidizers have been described; they were isolated from a deep-sea hydrothermal vent and a brackish lagoon $(4,31)$. Thus, there are only a very limited number of isolates of marine $\mathrm{Fe}$ (II)-oxidizing microorganisms, illustrating the need for further isolation attempts.

Autotrophic and mixotrophic nitrate-reducing $\mathrm{Fe}(\mathrm{II})$ oxidizers. While we were able to detect and also identify mixotrophic nitrate-reducing $\mathrm{Fe}$ (II) oxidizers in sediments from both studied field sites, we were unable to cultivate autotrophic nitrate-reducing $\mathrm{Fe}(\mathrm{II})$ oxidizers that could be transferred continuously with- out the addition of an organic cosubstrate. The rapid oxidation of $\mathrm{Fe}(\mathrm{II})$ in the first autotrophic transfers could be explained by organic compounds that were present in the sediment used for inoculation. The subsequent autotrophic dilution series still showed $\mathrm{Fe}$ (II) oxidation, but the cells were probably running out of stored organic material and were transiently using organic $\mathrm{C}$ from extracellular polymeric substances or from dead cell biomass for mixotrophic $\mathrm{Fe}(\mathrm{II})$ oxidation. Alternatively, other growth factors, such as vitamins, trace metals, or other bacteria, needed by the autotrophic nitrate-reducing $\mathrm{Fe}$ (II) oxidizers were no longer present after several dilutions, and the organisms were therefore not able to grow. Dependence of autotrophic nitrate-reducing Fe(II) oxidation on coculture strains is known for the autotrophic enrichment culture KS (4), for which organisms such as Bradyrhizobium, Rhodanobacter, or Nocardioides (77) are necessary for continuous autotrophic $\mathrm{Fe}$ (II) oxidation. Additionally, it was recently suggested that complexation of $\mathrm{Fe}(\mathrm{II})$ by humic substances could be important for autotrophic nitrate-reducing $\mathrm{Fe}(\mathrm{II})$ oxidizers (78), although that study failed to show that the bacteria can grow autotrophically over several transfers. Despite these shortcomings, it would be worthwhile to set up enrichment cultures for autotrophic $\mathrm{Fe}$ (II) oxidizers from the two sediments investigated here in the presence of humic substances or other organic Fe ligands, in particular for the Norsminde Fjord site, which contained the largest amount of organic matter. Such experiments will allow us to determine whether organically complexed $\mathrm{Fe}$ (II) is a suitable substrate for nitrate-reducing $\mathrm{Fe}(\mathrm{II})$ oxidizers, first, because its redox potential is more favorable for $\mathrm{Fe}(\mathrm{II})$ oxidation than dissolved $\mathrm{Fe}(\mathrm{II})$, and second, because after oxidation, the $\mathrm{Fe}(\mathrm{III})$ formed can potentially be complexed by the organic ligand as well, thus preventing cell encrustation by Fe(III) minerals (29).

Homogeneous depth distribution of $\mathrm{Fe}(\mathrm{II})$ oxidizers. Our MPN analyses showed that the different Fe-metabolizing bacteria constituted only a small percentage of the total bacterial community, with $5 \times 10^{-3} \%$ [microaerophilic $\mathrm{Fe}(\mathrm{II})$ oxidizers] to $3 \times$ $10^{-7} \%$ (photoferrotrophs) in Norsminde Fjord sediment and $8 \times$ $10^{-3} \%$ [microaerophilic $\mathrm{Fe}(\mathrm{II})$ oxidizers] to $6 \times 10^{-7} \%$ (photoferrotrophs) in Kalø Vig sediment. Similar low abundances for nitrate-reducing $\mathrm{Fe}(\mathrm{II})$ oxidizers and microaerophilic $\mathrm{Fe}(\mathrm{II})$ oxidizers were reported in previous studies on $\mathrm{Fe}(\mathrm{II})$ oxidation in soil and freshwater sediments $(79,80)$. These cultivation-based MPNs may strongly underestimate the true number of $\mathrm{Fe}(\mathrm{II})$-oxidizing bacteria in the sediment. Since in our calculations we compare the cultivation-based MPNs with the total cell numbers based on qPCR, the actual percentage of Fe(II) oxidizers is expected to be much higher, as can also be seen in our comparison of MPN and qPCR data for microaerophilic $\mathrm{Fe}$ (II) oxidizers, where cell numbers determined by qPCR were always higher than MPN counts. For comparison, MPN counts of sulfate-reducing bacteria in Norsminde Fjord (also called Kysing Fjord) obtained by a highly sensitive radiotracer MPN method were up to $10^{3}$-fold higher than standard MPN counts $(81,82)$. Based on the calculated mean cell-specific rates of sulfate reduction, those radiotracer MPN counts were probably still at least 2 orders of magnitude lower than the actual number of sulfate-reducing bacteria in situ (83).

Surprisingly, we found that the abundances of the different Fe-metabolizing bacteria did not significantly change with depth within the top $3 \mathrm{~cm}$ of the sediment. This was not expected, as profiles of $\mathrm{O}_{2}$ and light suggested that the different $\mathrm{Fe}$ (II) oxidizers could be active only in thin sediment layers with appropriate en- 
vironmental conditions. For example, $\mathrm{O}_{2}$ was available only in the uppermost $2 \mathrm{~mm}$ of the sediment, and consequently, we expected to find the highest abundances of microaerophilic Fe(II) oxidizers in this zone. However, abundances of microaerophilic Fe(II) oxidizers determined by two different cultivation-dependent MPN approaches (gradient tubes and ZVI plates) and by qPCR were constant down to a 3-cm sediment depth. We repeated the MPNs for the three different types of $\mathrm{Fe}$ (II) oxidizers at a higher spatial resolution of $0.2 \mathrm{~cm}$ instead of $0.5 \mathrm{~cm}$ as shown here (data not shown) but still found no distinct trend of depth distribution of the physiological groups of $\mathrm{Fe}(\mathrm{II})$ oxidizers. It has to be noted, however, that the activities of the different Fe(II) oxidizers at the different sediment depths are unknown, and we do not know whether, as could be expected, the activities of the Fe(II) oxidizers correlate with geochemical profiles in our sediments.

The homogeneous distribution of Fe(II) oxidizers could have different reasons. First, it could be that the Fe(II) oxidizers were distributed evenly in the sediment due to mixing by frequent wave action (84) or by bioturbating fauna, i.e., burrowing fauna that move surrounding sediment and pore fluid around in the upper layers of the sediment $(85,86)$. As a consequence, cells might be transiently dormant when conditions are not favorable for $\mathrm{Fe}$ (II) oxidation, and only the cells that are in sediment layers with favorable geochemical conditions at any given time would be actively oxidizing Fe(II). Bioturbation by burrowing fauna is well known from the upper 6 to $8 \mathrm{~cm}$ of Aarhus Bay sediments, where it was found to stimulate iron cycling by enhancing pore water exchange and by supplying solid-phase Fe(III) down to the Fe reduction zone and simultaneously transporting $\mathrm{Fe}$ (II) upward toward the sediment surface (47). Together with the mixing of sediment material, bacteria are also passively moved up and down in the sediment. Bioturbation in these sediments, and particularly the ventilation of worm burrows, probably takes place at a low rate to even greater depths of 10 to $20 \mathrm{~cm}$ and more (87). Another explanation for the more or less even distribution of these metabolic groups could be that $\mathrm{O}_{2}$ - and/or nitrate-rich microenvironments are created in different sediment layers due to the activity of the bioturbating and bioirrigating fauna, which we observed visually at both field sites. The activity of the animals creates microniches where oxygen and nitrate are locally available (88-90), potentially also allowing $\mathrm{Fe}$ (II) oxidation with oxygen or nitrate. The different polychaetes observed (Nereis sp. and Arenicola sp. at Norsminde Fjord and Kalø Vig, respectively) make 10- to 30-cmdeep burrows into the sediment. Also, crustaceans, such as the amphipod Corophium sp., burrow to 6-cm depth into the sediment (91). Such bioirrigation is dynamic and not easily picked up by microsensor measurements or pore water extraction. The walls of the holes of burrowing worms can be seen as an extension of the sediment surface, because the overlying water is actively flushed through the burrows (92-94). This means that the geochemical gradients extend laterally from the sides of the burrow. Oxygen or nitrate penetration from the burrow wall into the surrounding sediment can be similar to the penetration from the overlying water into the sediment surface (89). These changes in geochemical conditions have also been shown to influence microbial communities, e.g., the general biodiversity of a microbial community (95) or, more specifically, the microbial community linked to nitrogen cycling (88). In Kalø Vig sediment, the presence of seagrass could also be involved in $\mathrm{O}_{2}$ transport through plant roots into deeper sediment layers (96) and could facilitate the activity of microaerophilic Fe(II) oxidizers in sediment layers below the oxygen penetration depth. Although worm burrows were frequently observed, and although at the Norsminde Fjord site small polychaete worms were observed in almost every sediment core, we were not able to specifically sample the burrows, as they were either too small ( $<1 \mathrm{~mm}$ wide in Norsminde Fjord) or not included (in the case of the large Arenicola sp. in Kalø Vig) when we sliced the cores.

Identity of the $\mathrm{Fe}$ (II)-oxidizing bacteria. We were able to cultivate highly enriched cultures of all three types of Fe(II) oxidizers and of Fe(III) reducers from both field sites. The DGGE gels showed more than one band from most of the enrichments. However, all the sequences from these different bands appeared to be the same, according to the BLAST results, except for the photoferrotrophic enrichment culture from Kalø Vig, where we indeed found two different strains. Although from microscopy and sequencing of DGGE bands the enrichment cultures seem to be nearly pure, it still remains to be determined, by simultaneous hybridization with a specific and a general catalyzed reporter deposition (CARD)-fluorescence in situ hybridization (FISH) probe, how pure the enrichment cultures are.

Some close relatives of our enriched cultures are also known $\mathrm{Fe}(\mathrm{II})$ oxidizers. The $16 \mathrm{~S}$ rRNA sequence of our mixotrophic nitrate-reducing $\mathrm{Fe}(\mathrm{II})$-oxidizing enrichment culture from Norsminde Fjord is 99\% similar to that of Hoeflea siderophila, which was reported by Sorokina et al. (97) to be capable of mixototrophic nitrate-reducing $\mathrm{Fe}(\mathrm{II})$ oxidation, as well as lithoautotrophic $\mathrm{Fe}(\mathrm{II})$ oxidation, under micro-oxic conditions. For the other nitrate-reducing enrichment from Kalø Vig, the closest-relative $\mathrm{Fe}(\mathrm{II})$ oxidizer was Dechloromonas aromatica strain RCB (91\% sequence similarity), which is also capable of mixotrophic nitrate-reducing Fe(II) oxidation (98). The closest relatives of the anoxygenic phototrophic $\mathrm{Fe}(\mathrm{II})$-oxidizing Chlorobium strain, which we enriched from Norsminde Fjord, are not known to be able to oxidize $\mathrm{Fe}(\mathrm{II})$ but oxidize $\mathrm{H}_{2} \mathrm{~S}(99,100)$. However, another known Chlorobium strain that is phylogenetically more distantly related, i.e., Chlorobium ferrooxidans strain KoFox (93\% sequence similarity), which is a freshwater strain that lives in coculture with a Geospirillum strain (KoFum), is also able to oxidize Fe(II) photoautotrophically $(24,101)$. For most isolated and published Chlorobium strains, unfortunately, no information exists about whether they can oxidize iron, probably because this was not tested. In the photoferrotrophic enrichment culture from Kalø Vig, two different sequences were found. One was $98 \%$ similar to that of $M$. purpuratum, whose ability to oxidize Fe(II) is not known. The closest known relative able to oxidize Fe(II) is the freshwater photoferrotroph Rhodobacter sp. SW2, with only $84 \%$ sequence similarity. The second DGGE band in the enrichment culture showed $98 \%$ similarity to that of Rhodobacter sp. SW2, which was the first cultivated Fe(II)-oxidizing anoxygenic phototroph isolated from a freshwater pond (5). It is surprising that the isolated photoferrotrophs are more closely related to known freshwater photoferrotrophic strains than to the known marine representatives of this physiological group. However, so far, only two marine species of anoxygenic photoferrotrophs are known $(43,44)$, and there has been only a small amount of research on anoxygenic phototrophic $\mathrm{Fe}(\mathrm{II})$ oxidation in marine sediments.

The microaerophilic Fe(II)-oxidizing enrichments from Aarhus Bay were all closely related to Mariprofundus sp. M34, which was isolated as a microaerophilic Fe(II) oxidizer from a microbial 
mat at a deep-sea hydrothermal vent at Loihi Seamount (Hawaii) by McAllister et al. (76). Our study thus shows that microaerophilic $\mathrm{Fe}(\mathrm{II})$-oxidizing Zetaproteobacteria are also naturally present in coastal marine sediments.

Microbial Fe(II) oxidation in marine coastal sediments. Our findings raise the question of the extent to which these three metabolic types of $\mathrm{Fe}$ (II)-oxidizing bacteria contribute to $\mathrm{Fe}$ (II) oxidation in situ. Ideally, activity measurements in microcosms or sediment cores, in combination with RNA-based molecular analyses, are needed to answer this question. However, we can draw several conclusions based on the cell abundances and the geochemical profiles. For the photoferrotrophs, we determined very low abundances, and these organisms can also live on other types of metabolism than Fe(II) oxidation $(23,24,43,102)$. They may even prefer reduced sulfur species or organic acids over Fe(II). Based on microelectrode measurements taken at different times throughout the year (data not shown), we suggest that the photoferrotrophs mainly contribute to iron cycling in summer, since in winter, oxygen penetrated deeper into the sediment than light. In summer, however, the phototrophs would have a distinct advantage, since oxygen penetration was shallow, and the nitrate-reducing $\mathrm{Fe}(\mathrm{II})$ oxidizers would compete for the sparse nitrate from the water column with microphytobenthos on the sediment surface. Although the nitrate-reducing Fe(II) oxidizers were more abundant than the photoferrotrophs, we were unable to isolate autotrophic representatives. For the cultivated mixotrophic nitratereducing $\mathrm{Fe}(\mathrm{II})$ oxidizers, it could be that $\mathrm{Fe}(\mathrm{II})$ oxidation is not an enzymatic process but an abiotic side reaction caused by nitrite that is formed during heterotrophic denitrification (27). It could even be that this side reaction is unavoidable during denitrification in the presence of $\mathrm{Fe}$ (II) (28). Thus, such indirect Fe(II) oxidation could be important in nitrate- and organic-rich marine sediments, such as in Norsminde Fjord. The highest abundances of Fe(II) oxidizers in both sediments were those of the microaerophilic Fe(II) oxidizers, which we could assign to the Zetaproteobacteria. In contrast to the nitrate-reducing and phototrophic $\mathrm{Fe}(\mathrm{II})$ oxidizers, marine microaerophilic $\mathrm{Fe}(\mathrm{II})$ oxidizers belong to the Zetaproteobacteria, as the ones that we found in the two different sediments from Aarhus Bay appear to be metabolically very restricted. All currently known isolates originate from ironrich environments and are obligate microaerophilic $\mathrm{Fe}$ (II) oxidizers $(37,38,40,76)$. Although it was found that they carry the genes for nitrate reduction $(75,103)$, there is so far no evidence from growth experiments that they can actually live by that type of metabolism. Other microaerophilic Fe(II) oxidizers, e.g., different Leptothrix spp., are known to grow either by solely oxidizing organic carbon or by cometabolizing organic carbon and Fe(II) coupled with $\mathrm{O}_{2}$ reduction $(104,105)$. Therefore, it is particularly interesting to investigate the physiology of newly isolated strains of Zetaproteobacteria, and we expect that the microaerophilic $\mathrm{Fe}(\mathrm{II})$ oxidizers are the most important group of microbial $\mathrm{Fe}$ (II) oxidizers in Aarhus Bay sediments.

Microbial iron cycling in marine coastal sediments. Our data showed that $\mathrm{Fe}$ (III) reducers coexist with the three physiological types of Fe(II) oxidizers, even within the same sediment layers, thus allowing small-scale Fe cycling in microniches. Fe(III) reduction and sulfate reduction are the most important carbon mineralization pathways in the upper anoxic layers in marine sediments, and both lead to the production of $\mathrm{Fe}$ (II), either directly [enzymatic Fe(III) reduction] or indirectly [via abiotic Fe(III) reduc- tion by sulfide] $(9,106)$. Therefore, Fe(II) is readily available and constantly supplied in these marine sediments. The low concentrations of dissolved sulfide, the black sediment color, and the high Fe concentrations in Norsminde Fjord sediments suggest that the $\mathrm{Fe}$ (II) reacted effectively with sulfide and formed FeS. It is known that some Fe(II) oxidizers can use FeS as an Fe(II) source, e.g., photoferrotrophs, which can also oxidize other solid-phase substrates (4, 24, 107-109). For microaerophilic Fe(II) oxidizers, FeS is commonly used for cultivation in gradient tubes $(3,68)$, and they can also oxidize solid-phase substrates (110). Therefore, we expect that the FeS in the sediments investigated here is also bioavailable for microbial $\mathrm{Fe}(\mathrm{II})$ oxidation.

Conclusions and outlook. Based on the data presented in this study, we conclude that in coastal marine sediments, all three known metabolic types of $\mathrm{Fe}(\mathrm{II})$ oxidizers coexist together with $\mathrm{Fe}$ (III) reducers, and they are expected to contribute to Fe cycling in these sediments. This coexistence, however, could be caused simply by bioturbation and physical mixing, and it does not necessarily mean that the microbes are in direct competition or interact with each other. The $\mathrm{Fe}$ (II)-oxidizing activity of these bacteria should be clearly restricted to certain sediment layers by geochemical gradients, i.e., gradients of $\mathrm{O}_{2}$, light, $\mathrm{NO}_{3}{ }^{-}$, and $\mathrm{Fe}(\mathrm{II})$, with the exception of microniches, as they are, e.g., produced by burrowing animals. The next steps will be (i) to quantify the activities of the different $\mathrm{Fe}$ (II) oxidizers in natural marine sediments, (ii) to identify the most active members of the Fe(II)-oxidizing and $\mathrm{Fe}$ (III)-reducing community, and (iii) to determine how the different metabolic types of Fe(II) oxidation interact and compete, e.g., when geochemical gradients are changing, for example, in a diurnal cycle.

\section{ACKNOWLEDGMENTS}

We thank Ellen Struve for support with geochemical measurements, Karin Stögerer for help with the molecular biological analyses, and Wiebke Ruschmeier for the help with preparing gradient tubes. We thank Caroline Scholze for her support during sampling and help with cultivation and enrichment of microaerophilic Fe(II) oxidizers. We thank Michael Kühl and Lars Fledelius Rickelt (Copenhagen University), Jan Fischer (Pyro Science), and Martin Kristensen (Aarhus University) for supplying materials and know-how for the light sensors.

This project was supported by the European Research Council under the European Union's Seventh Framework Program (FP/2007-2013)/ ERC Grant, agreement no. 307320-MICROFOX.

\section{FUNDING INFORMATION}

EC | European Research Council (ERC) provided funding to Katja Laufer, Mark Nordhoff, and Andreas Kappler under grant number Agreement 307320-MICROFOX.

\section{REFERENCES}

1. Melton ED, Swanner ED, Behrens S, Schmidt C, Kappler A. 2014. The interplay of microbially mediated and abiotic reactions in the biogeochemical Fe cycle. Nat Rev Microbiol 12:797-808. http://dx.doi.org/10 .1038/nrmicro3347.

2. Lovley DR, Phillips EJP, Lonergan DJ. 1989. Hydrogen and formate oxidation coupled to dissimilatory reduction of iron or manganese by Alteromonas putrefaciens. Appl Environ Microbiol 55:700-706.

3. Emerson D, Moyer C. 1997. Isolation and characterization of novel iron-oxidizing bacteria that grow at circumneutral pH. Appl Environ Microbiol 63:4784-4792.

4. Straub KL, Benz M, Schink B, Widdel F. 1996. Anaerobic, nitratedependent microbial oxidation of ferrous iron. Appl Environ Microbiol 62:1458-1460.

5. Widdel F, Schnell S, Heising S, Ehrenreich A, Assmus B, Schink B. 
1993. Ferrous iron oxidation by anoxygenic phototrophic bacteria. Nature 362:834-836. http://dx.doi.org/10.1038/362834a0.

6. Lovley DR, Phillips EJP. 1988. Novel mode of microbial energy metabolism: organic carbon oxidation coupled to dissimilatory reduction of iron or manganese. Appl Environ Microbiol 54:1472-1480.

7. Weber KA, Achenbach LA, Coates JD. 2006. Microorganisms pumping iron: anaerobic microbial iron oxidation and reduction. Nat Rev Microbiol 4:752-764. http://dx.doi.org/10.1038/nrmicro1490.

8. Lovley D. 2006. Dissimilatory Fe(III)-and Mn(IV)-reducing prokaryotes, p 635-658. In The prokaryotes. Springer, New York, NY.

9. Thamdrup B. 2000. Bacterial manganese and iron reduction in aquatic sediments, p 41-84. In Schink B (ed), Advances in microbial ecology. Kluwer Academic/Plenum Publishers, New York, NY.

10. Ehrenberg GC. 1836. Vorlaufige Mitteilungen über das wirkliche Vorkommen fossiler Infusorien und ihre grosse Verbreitung. Poggendorff Ann 38:213-227.

11. Kucera S, Wolfe R. 1957. A selective enrichment method for Gallionella ferruginea. J Bacteriol 74:344.

12. Hallbeck L, Pedersen K. 1991. Autotrophic and mixotrophic growth of Gallionella ferruginea. J Gen Microbiol 137:2657-2661. http://dx.doi .org/10.1099/00221287-137-11-2657.

13. Druschel GK, Emerson D, Sutka R, Suchecki P, Luther GW. 2008. Low-oxygen and chemical kinetic constraints on the geochemical niche of neutrophilic iron(II) oxidizing microorganisms. Geochim Cosmochim Acta 72:3358-3370. http://dx.doi.org/10.1016/j.gca .2008.04.035.

14. Hegler F, Lösekann-Behrens T, Hanselmann K, Behrens S, Kappler A. 2012. Influence of seasonal and geochemical changes on the geomicrobiology of an iron carbonate mineral water spring. Appl Environ Microbiol 78:7185-7196. http://dx.doi.org/10.1128/AEM.01440-12.

15. Emerson D, Weiss JV. 2004. Bacterial iron oxidation in circumneutral freshwater habitats: findings from the field and the laboratory. Geomicrobiol J 21:405-414. http://dx.doi.org/10.1080/01490450490485881.

16. Fleming EJ, Langdon AE, Martinez-Garcia M, Stepanauskas R, Poulton NJ, Masland EDP, Emerson D. 2011. What's new is old: resolving the identity of Leptothrix ochracea using single cell genomics, pyrosequencing and FISH. PLoS One 6:e17769. http://dx.doi.org/10.1371 /journal.pone.0017769.

17. Winogradsky S. 1888. Über Eisenbakterien. Bot Ztg 48:261-271.

18. Emerson D, Rentz JA, Lilburn TG, Davis RE, Aldrich H, Chan C, Moyer CL. 2007. A novel lineage of proteobacteria involved in formation of marine Fe-oxidizing microbial mat communities. PLoS One 2:e667. http://dx.doi.org/10.1371/journal.pone.0000667.

19. Edwards KJ, Rogers DR, Wirsen CO, McCollom TM. 2003. Isolation and characterization of novel psychrophilic, neutrophilic, $\mathrm{Fe}$-oxidizing, chemolithoautotrophic alpha- and gamma-proteobacteria from the deep sea. Appl Environ Microbiol 69:2906-2913. http://dx.doi.org/10 .1128/AEM.69.5.2906-2913.2003

20. Bonis BM, Gralnick JA. 2015. Marinobacter subterrani, a genetically tractable neutrophilic Fe(II)-oxidizing strain isolated from the Soudan Iron Mine. Front Microbiol 6:719. http://dx.doi.org/10.3389/fmicb.2015 .00719 .

21. Kappler A, Pasquero C, Konhauser KO, Newman DK. 2005. Deposition of banded iron formations by anoxygenic phototrophic Fe(II)-oxidizing bacteria. Geology 33:865-868. http://dx.doi.org/10.1130/G21658.1.

22. Posth NR, Konhauser KO, Kappler A. 2013. Microbiological processes in banded iron formation deposition. Sedimentology 60:1733-1754. http://dx.doi.org/10.1111/sed.12051.

23. Jiao Y, Kappler A, Croal LR, Newman DK. 2005. Isolation and characterization of a genetically tractable photoautotrophic Fe(II)-oxidizing bacterium, Rhodopseudomonas palustris strain TIE-1. Appl Environ Microbiol 71:4487-4496. http://dx.doi.org/10.1128/AEM.71.8.4487-4496.2005.

24. Heising S, Richter L, Ludwig W, Schink B. 1999. Chlorobium ferrooxidans sp. nov., a phototrophic green sulfur bacterium that oxidizes ferrous iron in coculture with a "Geospirillum" sp. strain. Arch Microbiol 172: 116-124. http://dx.doi.org/10.1007/s002030050748.

25. Croal LR, Johnson CM, Beard BL, Newman DK. 2004. Iron isotope fractionation by $\mathrm{Fe}(\mathrm{II})$-oxidizing photoautotrophic bacteria. Geochim Cosmochim Acta 68:1227-1242. http://dx.doi.org/10.1016/j.gca.2003 .09 .011 .

26. Klueglein N, Kappler A. 2013. Abiotic oxidation of Fe(II) by reactive nitrogen species in cultures of the nitrate-reducing Fe(II) oxidizer Aci- dovorax sp. BoFeN1: questioning the existence of enzymatic Fe(II) oxidation. Geobiology 11:180-190.

27. Klueglein N, Zeitvogel F, Stierhof Y-D, Floetenmeyer M, Konhauser KO, Kappler A, Obst M. 2014. Potential role of nitrite for abiotic Fe (II) oxidation and cell encrustation during nitrate reduction by denitrifying bacteria. Appl Environ Microbiol 80:1051-1061. http://dx.doi.org/10 .1128/AEM.03277-13.

28. Carlson HK, Clark IC, Blazewicz SJ, Iavarone AT, Coates JD. 2013. $\mathrm{Fe}$ (II) oxidation is an innate capability of nitrate-reducing bacteria that involves abiotic and biotic reactions. J Bacteriol 195:3260-3268. http: //dx.doi.org/10.1128/JB.00058-13.

29. Schädler S, Burkhardt C, Hegler F, Straub KL, Miot J, Benzerara K, Kappler A. 2009. Formation of cell-iron-mineral aggregates by phototrophic and nitrate-reducing anaerobic Fe(II)-oxidizing bacteria. Geomicrobiol J 26:93-103. http://dx.doi.org/10.1080/01490450802660573.

30. Weber KA, Pollock J, Cole KA, O’Connor SM, Achenbach LA, Coates JD. 2006. Anaerobic nitrate-dependent iron(II) biooxidation by a novel lithoautotrophic betaproteobacterium, strain 2002. Appl Environ Microbiol 72:686-694. http://dx.doi.org/10 1128/AEM.72.1.686-694.2006.

31. Hafenbradl D, Keller M, Dirmeier R, Rachel R, Rossnagel P, Burggraf S, Huber H, Stetter KO. 1996. Ferroglobus placidus gen. nov., sp. nov., a novel hyperthermophilic archaeum that oxidizes $\mathrm{Fe} 2+$ at neutral $\mathrm{pH}$ under anoxic conditions. Arch Microbiol 166:308-314. http://dx.doi .org/10.1007/s002030050388.

32. Kumaraswamy R, Sjollema K, Kuenen G, van Loosdrecht M, Muyzer G. 2006. Nitrate-dependent [Fe(II)EDTA]2-oxidation by Paracoccus ferrooxidans sp. nov., isolated from a denitrifying bioreactor. Syst Appl Microbiol 29:276-286. http://dx.doi.org/10.1016/j.syapm.2005.08.001.

33. Finneran KT, Housewright ME, Lovley DR. 2002. Multiple influences of nitrate on uranium solubility during bioremediation of uraniumcontaminated subsurface sediments. Environ Microbiol 4:510-516. http://dx.doi.org/10.1046/j.1462-2920.2002.00317.x.

34. Li B, Tian C, Zhang D, Pan X. 2013. Anaerobic nitrate-dependent iron(II) oxidation by a novel autotrophic bacterium, Citrobacter freundii strain PXL1. Geomicrobiol J 31:138-144.

35. Benzine J, Shelobolina E, Xiong MY, Kennedy DW, McKinley JP, Lin X, Roden EE. 2013. Fe-phyllosilicate redox cycling organisms from a redox transition zone in Hanford 300 area sediments. Front Microbiol 4:388. http://dx.doi.org/10.3389/fmicb.2013.00388.

36. Kato S, Kobayashi C, Kakegawa T, Yamagishi A. 2009. Microbial communities in iron-silica-rich microbial mats at deep-sea hydrothermal fields of the Southern Mariana Trough. Environ Microbiol 11:20942111. http://dx.doi.org/10.1111/j.1462-2920.2009.01930.x.

37. Emerson D, Moyer CL. 2002. Neutrophilic Fe-oxidizing bacteria are abundant at the Loihi Seamount hydrothermal vents and play a major role in Fe oxide deposition. Appl Environ Microbiol 68:3085-3093. http: //dx.doi.org/10.1128/AEM.68.6.3085-3093.2002.

38. McBeth JM, Little BJ, Ray RI, Farrar KM, Emerson D. 2011. Neutrophilic iron-oxidizing "Zetaproteobacteria" and mild steel corrosion in nearshore marine environments. Appl Environ Microbiol 77:1405-1412. http://dx.doi.org/10.1128/AEM.02095-10.

39. Dang H, Chen R, Wang L, Shao S, Dai L, Ye Y, Guo L, Huang G, Klotz MG. 2011. Molecular characterization of putative biocorroding microbiota with a novel niche detection of Epsilon- and Zetaproteobacteria in Pacific Ocean coastal seawaters. Environ Microbiol 13:3059-3074. http: //dx.doi.org/10.1111/j.1462-2920.2011.02583.x.

40. Scott JJ, Breier JA, Luther GW, Emerson D III. 2015. Microbial iron mats at the mid-Atlantic ridge and evidence that zetaproteobacteria may be restricted to iron-oxidizing marine systems. PLoS One 10:e0119284. http://dx.doi.org/10.1371/journal.pone.0119284.

41. Rubin-Blum M, Antler G, Tsadok R, Shemesh E, Austin JA, Jr, Coleman DF, Goodman-Tchernov BN, Ben-Avraham Z, Tchernov D. 2014. First evidence for the presence of iron oxidizing zetaproteobacteria at the Levantine continental margins. PLoS One 9:e91456. http://dx.doi .org/10.1371/journal.pone.0091456.

42. McAllister SM, Barnett JM, Heiss JW, Findlay AJ, MacDonald DJ, Dow CL, Luther GW, Michael HA, Chan CS. 2015. Dynamic hydrologic and biogeochemical processes drive microbially enhanced iron and sulfur cycling within the intertidal mixing zone of a beach aquifer. Limnol Oceanogr 60:329-345. http://dx.doi.org/10.1002/lno.10029.

43. Straub KL, Rainey FA, Widdel F. 1999. Rhodovulum iodosum sp. nov. and Rhodovulum robiginosum sp. nov., two new marine phototrophic 
ferrous-iron-oxidizing purple bacteria. Int J Syst Bacteriol 49:729-735. http://dx.doi.org/10.1099/00207713-49-2-729.

44. Wu W, Swanner ED, Hao L, Zeitvogel F, Obst M, Pan Y, Kappler A. 2014. Characterization of the physiology and cell-mineral interactions of the marine anoxygenic phototrophic Fe(II)-oxidizer Rhodovulum iodosum: implications for Precambrian Fe(II) oxidation. FEMS Microbiol Ecol 88:503-515. http://dx.doi.org/10.1111/1574-6941.12315.

45. Emmerich M, Bhansali A, Losekann-Behrens T, Schroder C, Kappler A, Behrens S. 2012. Abundance, distribution, and activity of Fe(II)oxidizing and $\mathrm{Fe}(\mathrm{III})$-reducing microorganisms in hypersaline sediments of Lake Kasin, southern Russia. Appl Environ Microbiol 78:43864399. http://dx.doi.org/10.1128/AEM.07637-11.

46. Rowe AR, Chellamuthu P, Lam B, Okamoto A, Nealson K. 2014. Marine sediments microbes capable of electrode oxidation as a surrogate for lithotrophic insoluble substrate metabolism. Front Microbiol 5:784. http://dx.doi.org/10.3389/fmicb.2014.00784.

47. Thamdrup B, Fossing H, Jørgensen BB. 1994. Manganese, iron and sulfur cycling in a coastal marine sediment, Aarhus Bay, Denmark. Geochim Cosmochim Acta 58:5115-5129. http://dx.doi.org/10.1016 /0016-7037(94)90298-4.

48. Rasmussen H, Jorgensen BB. 1992. Microelectrode studies of seasonal oxygen-uptake in a coastal sediment-role of molecular-diffusion. Marine Ecol Prog Ser 81:289-303. http://dx.doi.org/10.3354/meps081289.

49. Jensen MH, Andersen TK, Sorensen J. 1988. Denitrification in coastal bay sediment: regional and seasonal variation in Aarhus Bight, Denmark. Mar Ecol Prog Ser 48:155-162. http://dx.doi.org/10.3354/meps048155.

50. Kühl M, Lassen C, Jorgensen BB. 1994. Light penetration and light intensity in sandy marine sediments measured with irradiance and scalar irradiance fiber-optic microprobes. Mar Ecol Prog Ser 105:139-148. http://dx.doi.org/10.3354/meps105139.

51. Billerbeck M, Røy H, Bosselmann K, Huettel M. 2007. Benthic photosynthesis in submerged Wadden Sea intertidal flats. Estuarine Coastal Shelf Sci 71:704-716. http://dx.doi.org/10.1016/j.ecss.2006.09.019.

52. Schmidt C, Behrens S, Kappler A. 2010. Ecosystem functioning from a geomicrobiological perspective: a conceptual framework for biogeochemical iron cycling. Environ Chem 7:399-405. http://dx.doi.org/10 $.1071 / \mathrm{EN} 10040$.

53. Canfield DE, Thamdrup B, Hansen JW. 1993. The anaerobic degradation of organic matter in Danish coastal sediments: iron reduction, manganese reduction, and sulfate reduction. Geochim Cosmochim Acta 57: 3867-3883. http://dx.doi.org/10.1016/0016-7037(93)90340-3.

54. Gerhardt S, Brune A, Schink B. 2005. Dynamics of redox changes of iron caused by light-dark variations in littoral sediment of a freshwater lake. Biogeochemistry 74:323-339. http://dx.doi.org/10.1007/s10533 $-004-4724-4$.

55. Kühl M, Jørgensen BB. 1992. Spectral light measurements in microbenthic phototrophic communities with a fiber-optic microprobe coupled to a sensitive diode array detector. Limnol Oceanogr 37:1813-1823. http: //dx.doi.org/10.4319/lo.1992.37.8.1813

56. Porsch K, Kappler A. 2011. FeII oxidation by molecular O2 during $\mathrm{HCl}$ extraction. Environ Chem 8:190-197. http://dx.doi.org/10.1071 /EN10125.

57. Stookey LL. 1970. Ferrozine: a new spectrophotometric reagent for iron. Anal Chem 42:779-781. http://dx.doi.org/10.1021/ac60289a016.

58. Widdel F, Pfennig N. 1981. Studies on dissimilatory sulfate-reducing bacteria that compose fatty acids. I. Isolation of a new sulfate-reducer enriched with acetate from saline enviroments. Description of Desulfobacter postgatei gen. nov sp nov. Arch Microbiol 129:395-400.

59. Tschech A, Pfennig N. 1984. Growth yield increase linked to caffeate reduction in Acetobacterium woodii. Arch Microbiol 137:163-167. http: //dx.doi.org/10.1007/BF00414460.

60. Widdel F. 1980. Anaerober Abbau von Fettsäuren und Benzoesäure durch neu isolierte Arten Sufat reduzierender Bakterien. Ph.D. thesis. Göttingen University, Göttingen, Germany.

61. Sørensen J. 1982. Reduction of ferric iron in anaerobic, marine sediment and interaction with reduction of nitrate and sulfate. Appl Environ Microbiol 43:319-324.

62. Parkes R, Gibson G, Mueller-Harvey I, Buckingham W, Herbert R. 1989. Determination of the substrates for sulphate-reducing bacteria within marine and estuarine sediments with different rates of sulphate reduction. J Gen Microbiol 135:175-187.

63. Straub KL, Kappler A, Schink B. 2005. Enrichment and isolation of ferric-iron- and humic-acid-reducing bacteria. Methods Enzymol 397: 58-77. http://dx.doi.org/10.1016/S0076-6879(05)97004-3.

64. Krepski ST, Hanson TE, Chan CS. 2012. Isolation and characterization of a novel biomineral stalk-forming iron-oxidizing bacterium from a circumneutral groundwater seep. Environ Microbiol 14:1671-1680. http://dx.doi.org/10.1111/j.1462-2920.2011.02652.x.

65. Hohmann C, Winkler E, Morin G, Kappler A. 2010. Anaerobic Fe(II)oxidizing bacteria show As resistance and immobilize As during Fe(III) mineral precipitation. Environ Sci Technol 44:94-101. http://dx.doi.org /10.1021/es900708s.

66. Trouwborst RE, Johnston A, Koch G, Luther GW III, Pierson BK. 2007. Biogeochemistry of $\mathrm{Fe}$ (II) oxidation in a photosynthetic microbial mat: implications for Precambrian Fe(II) oxidation. Geochim Cosmochim Acta 71:4629-4643. http://dx.doi.org/10.1016/j.gca.2007.07 .018 .

67. Wilbanks EG, Jaekel U, Salman V, Humphrey PT, Eisen JA, Facciotti MT, Buckley DH, Zinder SH, Druschel GK, Fike DA. 2014. Microscale sulfur cycling in the phototrophic pink berry consortia of the Sippewissett Salt Marsh. Environ Microbiol 16:3398-3415. http://dx.doi.org/10 $.1111 / 1462-2920.12388$.

68. Emerson D, Floyd MM. 2005. Enrichment and isolation of ironoxidizing bacteria at neutral pH. Methods Enzymol 397:112-123. http: //dx.doi.org/10.1016/S0076-6879(05)97006-7.

69. Klee AJ. 1993. A computer program for the determination of most probable number and its confidence limits. J Microbiol Methods 18:91-98. http://dx.doi.org/10.1016/0167-7012(93)90025-D.

70. Muyzer G, De Waal EC, Uitterlinden AG. 1993. Profiling of complex microbial populations by denaturing gradient gel electrophoresis analysis of polymerase chain reaction-amplified genes coding for $16 \mathrm{~S}$ rRNA. Appl Environ Microbiol 59:695-700.

71. Nadkarni MA, Martin FE, Jacques NA, Hunter N. 2002. Determination of bacterial load by real-time PCR using a broad-range (universal) probe and primers set. Microbiology 148:257-266. http://dx.doi.org/10.1099 /00221287-148-1-257.

72. Lane DJ. 1991. 16S/23S rRNA sequencing, p 115-175. In Stackebrandt EG, Goodfellow M (ed), Nucleic acid techniques in bacterial systematics. John Wiley and Sons, New York, NY.

73. Altschul SF, Gish W, Miller W, Myers EW, Lipman DJ. 1990. Basic local alignment search tool. J Mol Biol 215:403-410. http://dx.doi.org/10 .1016/S0022-2836(05)80360-2.

74. Singer E, Emerson D, Webb EA, Barco RA, Kuenen JG, Nelson WC, Chan CS, Comolli LR, Ferreira S, Johnson J, Heidelberg JF, Edwards KJ. 2011. Mariprofundus ferrooxydans PV-1 the first genome of a marine $\mathrm{Fe}(\mathrm{II})$ oxidizing Zetaproteobacterium. PLoS One 6:e25386. http://dx.doi org/10.1371/journal.pone.0025386.

75. Field EK, Sczyrba A, Lyman AE, Harris CC, Woyke T, Stepanauskas R, Emerson D. 2015. Genomic insights into the uncultivated marine Zetaproteobacteria at Loihi Seamount. ISME J 9:857-870. http://dx.doi.org /10.1038/ismej.2014.183.

76. McAllister SM, Davis RE, McBeth JM, Tebo BM, Emerson D, Moyer CL. 2011. Biodiversity and emerging biogeography of the neutrophilic iron-oxidizing Zetaproteobacteria. Appl Environ Microbiol 77:54455457. http://dx.doi.org/10.1128/AEM.00533-11.

77. Blöthe M, Roden EE. 2009. Composition and activity of an autotrophic $\mathrm{Fe}(\mathrm{II})$-oxidizing, nitrate-reducing enrichment culture. Appl Environ Microbiol 75:6937-6940. http://dx.doi.org/10.1128/AEM.01742-09.

78. Kanaparthi D, Conrad R. 2015. Role of humic substances in promoting autotrophic growth in nitrate-dependent iron-oxidizing bacteria. Syst Appl Microbiol 38:184-188. http://dx.doi.org/10.1016/j.syapm.2015.02 .009 .

79. Weiss JV, Emerson D, Backer SM, Megonigal JP. 2003. Enumeration of $\mathrm{Fe}(\mathrm{II})$-oxidizing and $\mathrm{Fe}(\mathrm{III})$-reducing bacteria in the root zone of wetland plants: implications for a rhizosphere iron cycle. Biogeochemistry 64:77-96. http://dx.doi.org/10.1023/A:1024953027726.

80. Straub KL, Buchholz-Cleven BE. 1998. Enumeration and detection of anaerobic ferrous iron-oxidizing, nitrate-reducing bacteria from diverse European sediments. Appl Environ Microbiol 64:4846-4856.

81. Jørgensen BB. 1978. A comparison of methods for the quantification of bacterial sulfate reduction in coastal marine sediments. III. Estimation from chemical and bacteriological field data. Geomicrobiol J 1:49-64.

82. Vester F, Ingvorsen K. 1998. Improved most-probable-number method to detect sulfate-reducing bacteria with natural media and a radiotracer. Appl Environ Microbiol 64:1700-1707. 
83. Hoehler TM, Jørgensen BB. 2013. Microbial life under extreme energy limitation. Nat Rev Microbiol 11:83-94. http://dx.doi.org/10 $.1038 /$ nrmicro2939.

84. Sunamura T, Kraus NC. 1984. Prediction of average mixing depth of sediment in the surf zone. Marine Geol 62:1-12. http://dx.doi.org/10 .1016/0025-3227(84)90051-3.

85. Teal L, Bulling M, Parker E, Solan M. 2008. Global patterns of bioturbation intensity and mixed depth of marine soft sediments. Aquat Biol 2:207-218.

86. Ferreira O, Ciavola P, Taborda R, Bairros M, Dias JA. 2000. Sediment mixing depth determination for steep and gentle foreshores. J Coastal Res 16:830-839.

87. Jørgensen BB, Parkes RJ. 2010. Role of sulfate reduction and methane production by organic carbon degradation in eutrophic fjord sediments (Limfjorden, Denmark). Limnol Oceanogr 55:1338-1352. http://dx.doi .org/10.4319/lo.2010.55.3.1338.

88. Laverock B, Gilbert J, Tait K, Osborn AM, Widdicombe S. 2011. Bioturbation: impact on the marine nitrogen cycle. Biochem Soc Trans 39:315. http://dx.doi.org/10.1042/BST0390315.

89. Kristensen E. 1985. Oxygen and inorganic nitrogen exchange in a "Nereis virens"(Polychaeta) bioturbated sediment-water system. J Coastal Res 1:109-116.

90. Kristensen E, Jensen MH, Andersen TK. 1985. The impact of polychaete (Nereis virens Sars) burrows on nitrification and nitrate reduction in estuarine sediments. J Exp Mar Biol Ecol 85:75-91. http://dx .doi.org/10.1016/0022-0981(85)90015-2.

91. Pelegrí SP, Blackburn TH. 1994. Bioturbation effects of the amphipod Corophium volutator on microbial nitrogen transformations in marine sediments. Mar Biol 121:253-258. http://dx.doi.org/10.1007/BF00346733.

92. Aller RC. 1982. The effects of macrobenthos on chemical properties of marine sediment and overlying water, p 53-102. In McCall PL (ed), Animal-sediment relations. Springer, New York, NY.

93. Jørgensen BB, Revsbech NP. 1985. Diffusive boundary layers and the oxygen uptake of sediments and detritus. Limnol Oceanogr 30:111-122. http://dx.doi.org/10.4319/lo.1985.30.1.0111.

94. Kristensen E. 2001. Impact of polychaetes (Nereis spp. and Arenicola marina) on carbon biogeochemistry in coastal marine sediments. Geochem Trans 2:92-103. http://dx.doi.org/10.1186/1467-4866-2-92.

95. Pischedda L, Militon C, Gilbert F, Cuny P. 2011. Characterization of specificity of bacterial community structure within the burrow environment of the marine polychaete Hediste (Nereis) diversicolor. Res Microbiol 162:1033-1042. http://dx.doi.org/10.1016/j.resmic.2011.07.008.

96. Ingemann Jensen S, Kühl M, Glud RN, Jørgensen LB, Priemé A. 2005. Oxic microzones and radial oxygen loss from roots of Zostera marina. Mar Ecol Prog Ser 293:49-58. http://dx.doi.org/10.3354/meps293049.

97. Sorokina AY, Chernousova EY, Dubinina GA. 2012. Hoeflea siderophila sp. nov., a new neutrophilic iron-oxidizing bacterium. Microbiology 81: 59-66. http://dx.doi.org/10.1134/S0026261712010146.

98. Salinero KK, Keller K, Feil WS, Feil H, Trong S, Di Bartolo G, Lapidus A. 2009. Metabolic analysis of the soil microbe Dechloromonas aromatica str. RCB: indications of a surprisingly complex life-style and cryptic anaerobic pathways for aromatic degradation. BMC Genomics 10:351. http://dx.doi.org/10.1186/1471-2164-10-351.

99. Pfennig N, Trüper HG. 1971. New nomenclatural combinations in the phototrophic sulfur bacteria. Int J Syst Bacteriol 21:11-14. http://dx.doi .org/10.1099/00207713-21-1-11.

100. Pfennig N, Trüper HG. 1971. Type and neotype strains of the species of phototrophic bacteria maintained in pure culture. Int J Syst Evol Microbiol 21:19-24.

101. Gauger T, Konhauser K, Kappler A. 2015. Protection of phototrophic iron(II)-oxidizing bacteria from UV irradiation by biogenic iron(III) minerals: implications for early Archean banded iron formation. Geology 43:1111-1112. http://dx.doi.org/10.1130/focus122015.1.

102. Ehrenreich A, Widdel F. 1994. Anaerobic oxidation of ferrous iron by purple bacteria, a new type of phototrophic metabolism. Appl Environ Microbiol 60:4517-4526.

103. Singer E, Heidelberg JF, Dhillon A, Edwards KJ. 2013. Metagenomic insights into the dominant $\mathrm{Fe}(\mathrm{II})$ oxidizing Zetaproteobacteria from an iron mat at Lo'ihi, Hawai'i. Front Microbiol 4:52. http://dx.doi.org/10 .3389/fmicb.2013.00052.

104. Vollrath S, Behrends T, Van Cappellen P. 2012. Oxygen dependency of neutrophilic Fe(II) oxidation by Leptothrix differs from abiotic reaction. Geomicrobiol J 29:550-560. http://dx.doi.org/10.1080/01490451.2011 .594147.

105. van Veen WL, Mulder EG, Deinema MH. 1978. The SphaerotilusLeptothrix group of bacteria. Microbiol Rev 42:329-356.

106. Canfield DE. 1989. Reactive iron in marine sediments. Geochim Cosmochim Acta 53:619-632. http://dx.doi.org/10.1016/0016 -7037(89)90005-7.

107. Hegler F, Posth NR, Jiang J, Kappler A. 2008. Physiology of phototrophic iron(II)-oxidizing bacteria: implications for modern and ancient environments. FEMS Microbiol Ecol 66:250-260. http://dx.doi.org /10.1111/j.1574-6941.2008.00592.x.

108. Bose A, Gardel EJ, Vidoudez C, Parra EA, Girguis PR. 2014. Electron uptake by iron-oxidizing phototrophic bacteria. Nat Commun 5:3391. http://dx.doi.org/10.1038/ncomms4391.

109. Byrne JM, Klueglein N, Pearce C, Rosso KM, Appel E, Kappler A. 2015. Redox cycling of Fe(II) and Fe(III) in magnetite by Femetabolizing bacteria. Science 347:1473-1476. http://dx.doi.org/10 $.1126 /$ science.aaa4834.

110. Summers ZM, Gralnick JA, Bond DR. 2013. Cultivation of an obligate $\mathrm{Fe}(\mathrm{II})$-oxidizing lithoautotrophic bacterium using electrodes. mBio 4:e00420-12. http://dx.doi.org/10.1128/mBio.00420-12.

111. Schmidle W. 1901. Neue Algen aus dem Gebiete des Oberrheins. Beih Bot Zentralbl 10:179-180.

112. Imhoff JF, Trüper HG. 1980. Chromatium purpuratum, sp. nov., a new species of the Chromatiaceae. Zentralbl Bakteriol C 1:61-69.

113. Rüger H-J, Höfle MG. 1992. Marine star-shaped-aggregate-forming bacteria: Agrobacterium atlanticum sp. nov.; Agrobacterium meteori sp. nov.; Agrobacterium ferrugineum sp. nov., nom. rev.; Agrobacterium gelatinovorum sp. nov., nom. rev.; and Agrobacterium stellulatum sp. nov., nom. rev. Int J Syst Evol Microbiol 42:133-143.

114. Coates JD, Chakraborty R, Lack JG, O'Connor SM, Cole KA, Bender KS, Achenbach LA. 2001. Anaerobic benzene oxidation coupled to nitrate reduction in pure culture by two strains of Dechloromonas. Nature 411:1039-1043. http://dx.doi.org/10.1038/35082545.

115. Weiner RM, Coyne VE, Brayton P, West P, Raiken SF. 1988. Alteromonas colwelliana sp. nov., an isolate from oyster habitats. Int J Syst Evol Microbiol 38:240-244. 